\title{
TRANSLATING SYMPATHY FOR DECEIVED CONSUMERS INTO EFFECTIVE PROGRAMS FOR PROTECTION
}

\section{INTRODUCTION}

Consumers, by definition, include us all. They are the largest economic group in the economy, affecting and affected by almost every public and private economic decision. Two-thirds of all spending in the economy is by consumers. But they are the only important group in the economy who are not effectively organized, whose views are often not heard. . . .

If consumers are offered inferior products, if prices are exorbitant, if drugs are unsafe or worthless, if the consumer is unable to choose on an informed basis, then his dollar is wasted, his health and safety may be threatened, and the national interest suffers. ${ }^{1}$

The public is constantly confronted with deceptive advertising, dishonest selling practices, and substandard workmanship and materials. At least two billion dollars' worth of counterfeit brand name goods will be sold in the United States this year. ${ }^{2}$ " $[\mathrm{F}]$ ix-up phonies' . . . are cheating American homeowners of an estimated billion dollars a year." 3 "One billion dollars was mentioned most often as the cost of quackery in the United States." 4

With the tremendous expansion of consumer credit since World War II ${ }^{5}$ and the accompanying "nefarious, unscrupulous and improper practices [that] exist in certain areas of consumer credit," ${ }^{6}$ an acute necessity for

1108 Cong. Rec. 4167, 4263 (1962) (message from President Kennedy to Congress concerning strength of programs to protect consumer interests). p. 28.

${ }_{2}^{2}$ Do You Know What You Are Buying?, Saturday Evening Post, July 9, 1955,

3 Dickenson, Watch Out for Phony Household Repairmen, Reader's Digest, Jan. 1962, p. 83.

4 Subconamttee on Frauds and Misrepresentations Affecting the Eldderly,

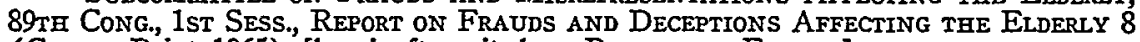
(Comm. Print 1965) [hereinafter cited as REPORT ON Frauds].

5 Total outstanding consumer credit (excluding real estate mortgage credit) grew from $\$ 7,222,000,000$ in 1939 to $\$ 69,890,000,000$ in 1963. 50 FED. RESERVE BuLL. 376 (1964). For a list of authorities concerning consumer credit see CurRan, Trends in Consumer Credit Legislation $1 \mathrm{n} .1$ (1965).

- Hearings Before Senate Committee on Banking, Commonzealth of Pennsylvania, in the Matter of: Commercial Credit Financing Fields, Pursuant to Senate Resolution, Serial No. 4, Sess. 1962, Philadelphia, Pennsylvania, May 15, 1963, at 19.

These hearings were conducted on four separate days : May 10, 1962, at Philadelphia, Pennsylvania; May 25, 1962, at Ridgway, Pennsylvania; June 13, 1962, at Pittsburgh, Pennsylvania; and May 15, 1963, at Philadelphia, Pennsylvania. The hearings will hereinafter be cited as "Donolow Committee Hearings" and the appropriate date will be included. 
protecting consumers has arisen. While consumer problems are to a great extent due to the exploitation of the elderly ${ }^{7}$ and the uneducated poor, ${ }^{8}$ the problems are by no means foreign to the better educated and wealthy. ${ }^{9}$ It is "incredible that a wealthy nation, priding itself on its enlightenment and its thirst for progress, should pay such a heavy penalty for ignorance or lack of adequate enforcement." 10

This Comment is the result of a field research project ${ }^{11}$ designed to ascertain what protection against fraudulent sellers is afforded the consumer and to suggest methods of achieving greater protection. Interviews with persons who in their organizational or governmental capacities might help the consumer more effectively were held in New Jersey, New York, and Pennsylvania, ${ }^{12}$ while correspondence was conducted with persons throughout the country. Special emphasis is given throughout the Comment to Pennsylvania problems and practices with an indication of the typical nature of the state's experience in particular areas.

Despite President Johnson's "intensified campaign . . . against the selfish minority who defraud and deceive consumers, charge unfair prices, or engage in other sharp practices," 13 despite movements in many states to set up consumer councils, ${ }^{14}$ and despite greater awareness of consumer

7 " $[\mathrm{I}] \mathrm{t}$ is shameful that the elderly of the United States are now clearly the major victims of the highly organized, high-pressure techniques of the modern day medicine man." REPORT ON FRAUDS 1. See generally id. at 1-77.

8 Caplovitz, Consumer Problems, 23 LEgal Am BRIEF CASE 143 (1965); 110 Cong. Rec. 1958, 1960 (1964) (message from President Johnson to Congress concerning consumer interests).

${ }^{9}$ An important trade union officer, high in the councils of the labor movement in the Commonwealth of Pennsylvania admitted to me readily that he has on at least a half dozen occasions been the victim of such high pressure salesmanship at a time when he himself was engaged in lecturing trade union audiences about the need for exercising care and caution in entering into installment sales agreements.

Donolow Committee Hearings, May 15, 1963, p. 13 (testimony of Harry Boyer, President, Pennsylvania AFL-CIO).

10 Report on Frauds 1.

11 The Law Revieze wishes to express its appreciation to the Thomas Skelton Harrison Foundation for providing funds so that an interview method of research could be employed in this study.

. 12 Personal interviews were held during the summer of 1965 with district attorneys, better business bureau representatives, editorial staffs of consumer testing magazines, police detectives, bank and finance company counsel and management, consumer council staffs, deputy attorneys general, post office inspectors, legal aid counsel, a magistrate, a United States attorney, newspaper advertising managers, state senators, senate investigating committee counsel, and numerous private attorneys.

Where the person interviewed is a member of a class of persons who might be expected to provide similar information about a particular facet of the consumer fraud problem, only his position is indicated, either in the text or footnote. Names of persons quoted are supplied only where identity is particularly relevant.

13110 Cong. REc. 1958, 2095 (1964) (message from President Johnson to Congress concerning consumer interests).

14 See National Better Business Bureau, The Growth of State Consumer Frauds Bureaus, June 1965; Warne, Consumer Protective Movements on the State and Local Levels-1964, May, 1964 unpublished manuscript on file in Biddle Law Library, University of Pennsylvania. See also pp. 430-34 infra. 
problems on the local level, ${ }^{15}$ the consensus among those interviewed was that the defrauded consumer had very little chance of obtaining satisfactory relief. The consumer is faced by a set of legal concepts traditionally premised on the "caveat emptor" doctrine. ${ }^{16} \mathrm{He}$ is unprotected by state legislatures since no lobby exerts pressure for laws to protect him, ${ }^{17}$ and sellers cheat him because of a belief that they are "locked in a no-holds-barred contest forced on . . . [them] by cutthroat competition." 18

While the solution proposed by many is business self-regulation, ${ }^{19}$ unethical techniques seem to be an inevitable by-product of competitive pressures which show little sign of diminishing; ${ }^{20}$ thus, while self-regulation presents business men with a "fascinating challenge," 21 it does not seem that it will prove effective in the near future. ${ }^{22}$ Sophistication of the consumer by education may be a long term goal-in the inevitable interim, however, supervision of business must be explored.

In order to illustrate the problems of the defrauded purchaser, the following case study is presented. Although it is fictional, it represents a typical consumer's experience.

The following advertisement appeared in Tom Conwell's local newspaper:

15 See discussion of the Frauds Division of the Philadelphia District Attorney's Office, at pp. 434-36 infra. An assistant district attorney stated that the bureau was set up only because no other group was helping the public.

16 See Hamilton, The Ancient Maxim Caveat Emptor, 40 Y ALE L.J. 1133 (1931).

"The conscious defrauder has been, and in many courts still is, treated more tenderly than other wrongdoers; the interests of those who have suffered at his hands have been traditionally only grudgingly protected." Seavey, Caveat Emptor as of 1960, 38 Texas L. Rev. 439 (1960).

17 This was the consensus of those interviewed. See also 108 Cong. Rec. 4167, 4263 (1962) (message from President Kennedy to Congress concerning consumer interests); California Consumer Counsel Rep. 3 (1962).

18 Home Furnishings Daily, July 14, 1958, p. 1, col. 2-3. This "no holds barred contest" rationale provides the basis for a series of articles describing the selling techniques adopted by the author (an anonymous appliance salesman in New York City) and suggested for use by other television and appliance retailers in the area, who are, as the introduction to the series describes it, "ground between the millstones of franchises on one hand and ruthless bargaining by consumers on the other. . ." Ibid. The series, entitled $A$ Salesman Says, appeared consecutively in the July $14-28$ issues of the Home Furnishings Daily, the newspaper of the home furnishings industry. For a summary of this series see Confessions of an Appliance Salesman, 23 CoNSUMER REPORTS 546 (1958).

19 "Finance men . . . state that over the years we cleaned our house pretty well with billions of abuses and billions of dollars at stake anyone can be damn sure that in the meantime we are watching and correcting real abuses closer and faster than anywhere else." Unpublished maunscript by Aaron Gold, President of Oxford Finance Company, Philadelphia, Pennsylvania, pp. 6-7 on file in Biddle Law Library, University of Pennsylvania. See generally National BetTer Business BUREaU, MAKING Self-Regulation a Reality, Report on Operations 1964 (1964); SMITH, Self-Regulation in Action . - Story of the Better Business Bureaus 19121962 (1961) [hereinafter cited as Self-Regulation].

20 Many businessmen interviewed were willing to rationalize unethical practices on the theory that "you can't cheat an honest man."

21 SelF-Regulation 3.

22 Senator WILlaAMs: If we wait for effective self-regulation I imagine we will be waiting a long, long time, won't we?

Mr. Hoffman: [testifying for the National Better Business Bureau]: It is conspicuous by its absence at the present time. REPORT ON FrAUDS 3. 
Unprecedented Carpet Value! ${ }^{23}$ September Clearance Sale! 24 Nationally Advertised Broadloom Rugs. $100 \%$ Nylon ${ }^{25}$ at $60 \%$ off. ${ }^{26}$ No Gimmicks. No Extras. Buy 6 areas of Wall to Wall Carpeting for $\$ 150 .{ }^{27}$ Call Now-National Carpet Fiesta, Inc. ${ }^{28}$ $594-7060$.

Tom read and reread the ad. Although the family budget did not seem to allow for the purchase of badly needed carpeting, he felt that it would not hurt to talk to the sales representative.

The salesman told Tom about a great new promotion plan through which Tom could earn twenty-five dollars for each person who bought carpeting from National Carpet Fiesta after being referred by him. The plan would enable Tom not only to pay for the carpets but also to make additional money. ${ }^{29}$ The salesman advised Tom to purchase "quality" carpets selling for the reduced price of 325 dollars rather than the "inferior"

23 The department of advertising acceptability of the New York Times has found this phrase to be "untrue, deceptive or misleading" and therefore unacceptable. NEW York Times, Standards of ADVERTISING ACCEPTABILITY 6 (1964). Advertisements in other prominent newspapers, however, contain constant references to the phrases the Times considers misleading. Thus a better business bureau recently wrote a letter to a company advertising, "Lowest Prices in Town" requesting them to discontinue the advertisement. Compare New York Times, Standards of Advertising ApPLICABILITY 6 (1964).

24 Statements announcing a "once-a-year clearance" or "bi-annual sale" are often meaningless. Compare Philadelphia Inquirer, June 6, 1965, p. 44 (advertisement for June clearance sale) werith Philadelphia Bulletin, June 6, 1965, p. 8 (same advertisement as Inquirer advertisement, supra, except no mention of "June Clearance") and Philadelphia Inquirer, July 18, 1965, p. 36 (same advertisement as Inquirer advertisement supra, except no mention of "Clearance").

25 The fiber alone . . . is no assurance of quality. The important point is how the fiber is used, how much of it is used, how it is built into the fabric, and whether the carpet is well made in other respects. . . "Broadloom" only means that the product was made on a broad loom, and the best and worst can be made on a broad loom. The $100 \%$ nylon or wool fiber is of little value if the pile is loose or thin. There are even rugs or carpets where the pile fiber is glued instead of being woven!

Tips on Buying Rugs and Carpeting, 44 The Shield, No. 4, Feb. 15, 1964.

26 The question is $60 \%$ of what? This is normally $60 \%$ off of a highly inflated price. For an amusing suggestion as to the method by which prices may be set, see Siegel, Mad's Discount Center Owner of the Year, More Trash From Mad 15-16 (1965).

27 "Never buy carpet on the basis of price alone. Question the advertisements which offer too much for too little. . ." Tips on Buying Rugs and Carpeting, 44 The Shield, No. 4, Feb. 15, 1964.

28 [M] any small and "fly by night" operators adopt a name that sounds very impressive and resembles, perhaps, one which has a high standing and reputation, often including words such as "International," "U.S." . . . or the name of a state, which seems to give them size and stature, or suggests a large and responsible organization.

Consumer Bull., March, 1964, p. 39.

29 Millions of dollars annually are being taken from the public by "chain referral" schemes embodying false and fraudulent misrepresentations. U.S. POST OFFICE DEP'T, How the Postal Inspectron Service Protects You Against MaIl Fraud (1964); see National Better Business Bureau, "Referral" Schemes (Safeguard series), on file in Biddle Law Library, University of Pennsylvania.

The use of the mail in furtherance of referral schemes has been held to be illegal under postal lottery and fraud laws, 18 U.S.C. $\$ \$ 1302,1341$ (1964) ; National Better Business Bureau, supra; U.S. Post Office Dep't, Inspection Service Buil. No. 29, at 6 (1965). Many states have outlawed the referral schemes. U.S. Post OFFICE DEP'T, 
150 dollar carpeting. ${ }^{30}$ Since Tom's carpets were to be used for referral purposes, however, he could purchase them at the cost price of 250 dollars, ${ }^{31}$ plus a thirty dollar installation fee and five dollars for a credit check. ${ }^{32}$ The salesman assured Tom that he could afford the interest charge of less than a dollar a week. ${ }^{33}$ Since Tom's future commissions were to cover his costs, all these terms were presented as mere formalities. When Tom hesitated, the salesman promised that the carpeting would be installed the next day and that he need pay nothing down, only five dollars for a credit check and a five dollar service charge for preparing the contract. ${ }^{34}$ Tom signed a blank contract after the salesman told him that his secretary would insert the details they had agreed upon. ${ }^{35}$

After a few days Tom received a letter from a finance company which, in part, stated:

\section{Dear Friend:}

In view of your excellent credit rating and fine character references, the Consumer Finance Companies, Inc., have agreed to finance your recent purchase of a carpet from the National Carpet Fiesta, Inc. In order to better serve you we would appreciate your answering the statements below and returning this form to us.

How the Postal Inspectron Service Protects You Against Mant Fraud (1964). Referral sales contracts may be voidable under state securities transactions laws against both the retailer and the finance company. See, e.g., Ohio Consumer Frauds and Crimes Bull. 8-102-63 (Aug. 1963), on file in Biddle Law Library, University of Pennsylvania. But see CAL. Crv. CoDE $\$ 1803.2$ (a) (expressly permits referral schemes under certain circumstances). For a discussion of referral in California, stating that there is a clear state policy against such schemes, see CALIFORNIA CONSUMrer CoUnSEL REP. 3 (1962).

30 The salesman never intended to sell Tom the $\$ 150$ carpet. His method of introducing a consumer to a higher priced item, known as "burning," which involves criticizing the brand the customer wants, is justified by a salesman on the ground that "after all, it is only a question of survival." Home Furnishings Daily, July 15, 1958, p. 1, col. 2-3.

31 "[T] here are whole industries which sell at discount rates frequently equal to cost only because their service charges and interest rates are so large as to provide most profitable margins." Donolow Committee Hearings, May 15, 1963, at 11 (testimony of Harry Boyer, President, Pennsylvania AFL-CIO).

32 "Installation charges are another good bit for add-ons. . . . But there's another add-on wrinkle $I$ use to even up with a chiseler when ail other means are exhausted. - . This is my credit investigation and set-up fee-the charge, a modest \$5." Home Furnishings Daily, July 25, 1958, p. 12, col. 1-2.

33 Although the interest rate may fall within legal limits, salesmen employ the technique of stating the charge in per week or per month amounts instead of stating the relatively higher sounding but more meaningful rate per year. Home Furnishings Daily, July 22, 1958, p. 20, cols. 2-3.

34 "I'll give you this set in your house tomorrow without a penny down. . . . My pal makes out the urder, extracts $\$ 5$ or $\$ 10$ towards 'sales tax' to tie him down, and stalls delivery until he gets an O.K. from the bank." Home Furnishings Daily, July 14,1958 , p. 1 , col. 1 .

35 "[L]ots of guys I know still give the customer only a blank contract to sign even though the interest rates may be standard ones." Home Furnishings Daily, July 22,1958 , p. 20, cols. 1-2. 
I understand we have signed an instrument which provides for 36 monthly payments of $\$ 12.20$ per month . . . .

First payment due October $1 .^{36}$

Though not taking account of Tom's expected commissions, the terms were correct, so he signed and mailed the paper to the finance company. Tom never received a copy of his contract with National Carpet Fiesta and the carpets were not delivered for two weeks; trouble at the factory was the reason given for the delay. When the workmen finally installed the carpets, Tom found that his floors had been damaged and that the carpet's ends were frayed.

The next day Tom tried to reach the salesman but was told that he no longer worked for the company and that another representative would call him. Receiving no response from the company for several days, Tom took time off from work and went to the company's office. The visit was futile since no one could see him until the following week.

Since it would be impossible to earn referral commissions until the carpets were repaired, Tom refused to make the first payment when it became due. The finance company sent a polite note asking for payment, but made clear that action would be taken if payment were not forthcoming. Tom again visited National Carpet Fiesta. The company denied all responsibility, claiming that the problem was due to faulty installation by the Apex Service Company, ${ }^{37}$ and refused to make any payment adjustments. A telephone call to Apex produced the information that they were no longer in business.

By this time the second payment was past due and the finance company's letters were more threatening. A third trip to the carpet company again brought no results. When Tom went to the finance company, he was informed that he would have to pay and could make adjustments only with the carpet company. When Tom objected he was shown the form he had signed and returned to the finance company. The fourth paragraph read:

The Consumer Finance Companies, Inc., cannot accept any responsibility for your purchase; and offers no guarantee that the representations made to you by the seller of the purchased item is correct. We Are a Financing Institution Only. Our only commodity is money. ${ }^{38}$

36 This is the first part of a form letter sent by an important Philadelphia finance company to a consumer before his paper is purchased. The president of the company calls this his "mouch letter." Note that this letter does not tell the consumer what his total charges are. $\mathrm{He}$ is given only the monthly payment rate. Compare note 33 supra.

37 A salesman states that he never lets complaints bother him once the item has left the store. Home Furnishings Daily, July 18, 1958, p. 12, cols. 1-2.

38 This is the next paragraph of the consumer letter cited note 36 supra (emphasis in original). At this point the company has the letter signed by the consumer in which it denies all responsibility for the sale. 
Tom had read this before, but had not realized that he would have to pay the finance company even if the carpets were defective. In spite of this he refused to pay until the carpets were repaired. ${ }^{39}$

The finance company then sent another letter advising him that judgment had been entered on the note he had signed. The company threatened to levy against his household furnishings if he did not pay the entire balance immediately. Not knowing where to find assistance, ${ }^{40}$ Tom followed a neighbor's suggestion and went to the better business bureau believing that the bureau would force the company to replace the carpets. ${ }^{41}$

At the bureau he filled out a complaint form ${ }^{42}$ which would be sent to the carpet company. He also was informed that he would be notified of the company's response. ${ }^{43}$ A few days later he learned that the company had denied responsibility. When he asked whether he should make any payments he found that the bureau "does not handle matters which require the services of an attorney," 44 and that he would have to engage a lawyer to settle his disagreement. He was told that he might try the district attorney's office and was given a pamphlet on "referral schemes." 45

Annoyed that the bureau could not help him, he decided to write to the chamber of commerce. The prompt reply was: "We wish to inform you that any complaints of the above sort-are forwarded to the Better Business Bureau. . . . We take no action at this office." 46

Deciding that he could not afford to pay an attorney he then went to the district attorney's office. A detective heard the complaint and made a phone call to the carpet company which again refused to make any adjustment. In the detective's opinion, no criminal fraud was involved and Tom

39 "Some families capable of maintaining payments stopped paying when they discovered that they had been cheated; but instead of gaining retribution, they were more often subjected to legal sanctions brought upon them by the merchant." Caplovitz, supra note 8, at 147. Accord, Philadelphia District Attorney James C. Crumlish who states that "before he knows it, there has been an execution on the note and his house is about to be sold from uncer him. . . ." Donolow Committee Hearings, May 10,1962 , at 145 .

40 In a study of consumer problems of low income families, it was found that "when asked directly where they [low income families] would go for help if they found themselves being cheated by a merchant, some 64 per cent said they did not know." Caplovitz, supra note 8, at 147.

41 The better business bureau, while not a law enforcement agency and hence not very helpful for this purpose, see note 59 infra and accompanying text, "was the agency most often cited by the minority who had some idea where they could go for professional help." Caplovitz, supra note 8, at 147.

42 A better business bureau "Customer Experience Record" is on file in Biddle Law Library, University of Pennsylvania.

43 Interview With Better Business Bureau Official.

44 National Better Business Bureau, Your Better Business Bureau (Safeguard Series), on file in Biddle Law Library, University of Pennsylvania [hereinafter cited as Your Better Business Bureau].

45 National Better Business Bureau, "Referral" Schemes (Safeguard Series), on file in Biddle Law Library, University of Pennsylvania.

${ }^{46}$ Letter From the Philadelphia Chamber of Commerce to the University of Pennsylvania Law Review, June, 1965, on file in Biddle Law Library, University of Pennsylvania. 
was advised to see a private attorney for advice on the civil question. ${ }^{47}$ However, the detective told him that if he wished to prosecute he could file a criminal complaint with a justice of the peace. If the justice of the peace found the complaint meritorious, Tom would have to pay the costs of issuing a private warrant. He then would have to appear before the justice of the peace at a preliminary hearing and, if the defendant was bound over for the grand jury, Tom again would have to appear. Finally, if a true bill were found by the grand jury, the district attorney would intervene as prosecutor and Tom would have to appear as a witness at the trial. 48 Since the detective had felt that no criminal fraud was involved, and since the proceedings would require Tom to spend a great deal of time away from work, he decided not to prosecute.

Two mornings later a deputy sheriff came to Tom's house with a paper entitled "sheriff's levy" on which he itemized Tom's household goods and furniture. The levy notice stated that: "All household goods and furnishings have been levied upon by the Sheriff's Office and will remain their [sic] property until disposed of. In the meantime they can neither be moved or sold." 49

Tom's complaint to the finance company concerning the levy resulted only in its credit manager showing him the form he signed when he purchased the carpets. It provided that:

Upon maturity or in the event any monthly payment is not paid when due, the whole unpaid balance shall forthwith, without notice or demand, become due and payable at the option of the holder of this note and the undersigned authorizes and empowers any prothonotary or clerk or attorney of any court of record of the Commonwealth of Pennsylvania . . . at any time or times, to appear for and confess judgment against the undersigned. ... ${ }^{50}$

Although unable to decipher all the legal language, he realized that the finance company could remove his furniture. Tom threatened to sue unless he was given new carpets or the contract was torn up. The manager told him, however, that the finance company was legally protected as

47 This is the practice of the Frauds Division of the Philadelphia District Attorney's office, which effectively aids consumers with civil complaints in spite of its policy that when the problem is a civil matter, "the District Attorney's Office will advise the complainant to seek the services of a qualified attorney." The District Attorney's Office [Philadelphia], Public News Bull. No. 2 (1964); see pp. 434-36 infra.

48 In most counties the district attorney will not initiate prosecution in small fraud cases, but will send the complainant to start his own proceedings. Interviews With District Attorneys.

49 A sheriff's levy which was served on a consumer who missed payments on an installment contract is on file in Biddle Law Library, University of Pennsylvania.

$50 \mathrm{~A}$ copy of the confession of judgment which retail installment purchasers in Pennsylvania sign as part of the contract of sale with the dealer is on file in Biddle Law Library, University of Pennsylvania. 
a "holder in due course" 51 and reminded him of the letter they had sent him soon after the sale which informed him that it did not accept responsibility for his purchase.

Tom finally decided to see a private attorney, but the result again was disappointing. The lawyer told him that the finance company was protected by law and that he would have to pay them. An action against the carpet company might gain Tom about one hundred dollars, if successful, but even if the attorney charged the minimum bar association fees, it would cost Tom at least that much to proceed. ${ }^{52}$ He suggested that Tom go to the legal aid for help..$^{53}$

That evening, a man came to his home, identified himself as a constable, and presented Tom with a warrant for his arrest. The constable told Tom that he was being arrested for fraudulent conversion and secreting property with intent to cheat and defraud, and that he would have to come to the Consumer Finance Company offices. At the finance company, the constable, in the presence of a finance company representative, informed him that he would either have to pay this debt or go to jail. He was released after promising to pay early the following week..$^{54}$

Tom then contacted the legal aid society in a final attempt to gain protection. When he arrived, he filled out a form requiring information about himself and his family assets. He was then informed that he could not be represented by legal aid. His income was in excess of the maximum allowed, and therefore he did not qualify as a poor person..$^{55}$

The result of Tom's experience was a bill of 450 dollars owed to the finance company, six areas of frayed and faded carpets, and a realization that "nobody is doing anything to help the consumer." 56

51 See Uniform Commercial Code $\S \S 3-302,3-304,3-305$. See also discussion at pp. 414-18 infra.

52 The minimum fee schedule adopted by the Philadelphia Bar Association, December 29, 1964, indicates minimum civil practice fees of $\$ 25$ an hour for preparing a brief, $\$ 50$ for attending a pretrial conference, and $\$ 200$ for each day in court.

63 Every lawyer interviewed held the view expressed by Pennsylvania State Senator Rowland B. Mahany that most lawyers in this instance would send the client home.

54 A recent report states that although "it is a fundamental principle of law that a criminal prosecution may not be used to collect a civil debt," such practice is not uncommon in Philadelphia. Report of tHe AtToRney GeNeral on the INvestigaTION OF THe Magisterial Systear $439-49$ (1965) [hereinafter cited as Magistrates REPORT].

55 Legal aid counsel in Pittsburgh, Pennsylvania, and Camden, New Jersey, indicated that their staffs were too small to handle cases where a man had enough income to hire a lawyer even if no lawyer would accept his case. Robert D. Abrahams, Esq., legal counsel for the Philadelphia Legal Aid Society, contends that his branch will represent a consumer in this situation if he can find no lawyer to take his case. See also pp. 409-10 infra.

56 This was also the answer given by a prominent Philadelphia attorney when explaining why he accepted the position of consumer counsel with a state committee in Harrisburg investigating credit practices. His motive for accepting the position was not an altruistic desire to aid his follow man but a realization that while the banking or finance company counsel would be besieged by groups and other attorneys pressuring him to support their position, no one would bother him as consumer counsel and "I could spend more time here in Philadelphia with my wife and kids." 


\section{Nongovernmental Protection}

\section{A. The Better Business Bureau}

"When [consumers were] asked directly where they would go for help if . . . cheated by a merchant. . . . the Better Business Bureau was the agency most often cited by the minority who had some idea where they could go for professional help." 57 Tom's neighbors imagine that the bureau is an organization that gives recommendations and endorsements, passes judgment on the quality of merchandise, and recovers money from unscrupulous businessmen; ${ }^{58}$ they are, however, misinformed. ${ }^{59}$ While the better business bureau does aid the public, its effectiveness lies somewhere between this widely held image and the conception of some attorneys that "unfortunately, the Better Business Bureau doesn't do a thing to help people." ${ }^{\circ}$

Unlike consumer protection organizations whose funds are provided by government or by consumers, "the Better Business Bureau is . . . an independent agency of Business, organized as a non-profit corporation which is financed entirely by membership dues or subscriptions voluntarily paid to it by responsible business and professional firms." 61

The bureau's program includes direct contact with the public. ${ }^{62}$ In large part, this consists of answering inquiries from consumers concerning the reliability of firms with which they plan to do business. ${ }^{83}$ Had Tom called before dealing with the carpet company, however, as the bureau recommends, ${ }^{64}$ he would have been refused any information over the telephone and would have received only a letter stating the number of complaints registered against the company during the last three years and the number the company answered. ${ }^{65}$ Further questioning of the bureau would have been unproductive, since the bureau does not disclose the con-

57 Caplovitz, Consumer Problems, 23 LEgaL Am BRIEF CASE 143, 147 (1965) (study of consumer problems of New York low income families).

58 See note 41 supra and accompanying text.

59 Your Better Business Bureau.

60 Interview With Member of Philadelphia's "Neighborhood Law Office" Program. This feeling was echoed by a number of other attorneys interviewed.

61 Your Better Business Bureau.

62 The Bureau was founded in 1912 by a group of businessmen as a "vigilance committee" to eliminate abuses and create codes and standards in the field of advertising. SELF-REgulation 8. By emphasizing to the public that "the poor ethics of the few did not represent the policies and practices of all advertisers," ibid., these executives hoped to restore public confidence in their profession. Id. at 17, 18 .

63 More than two million inquiries were made by businessmen and consumers in 1962. Your Better Business Bureau. Seventy-two percent of the nearly three million "instances of service" reported by 104 better business bureaus in 1964 were inquiries. Betrer Business Bureau, Statistics For 1964, Table I (1965).

64 Your Better Business Bureau.

65 In order to gain first hand knowledge of bureau procedure, an editor of the University of Pennsylvania Law Review telephoned to inquire about the reliability of a particular carpet company whose advertisement had appeared in three Philadelphia daily newspapers. The report he received containing the above information, as well as a statement that "this bureau does not make recommendations nor give advice," is on file in Biddle Law Library, University of Pennsylvania. 
tent of complaints nor does it state whether the company has taken any action to rectify them. ${ }^{66}$ The ineffectiveness of this method has been noted by the bureau.

[A] flat "yes" or "no" answer to a call about whether we've "had any complaints against the XYZ Company" would really tell the inquirer nothing. . . . The kind of complaints would be important. . . . Our report must give the whole picture. In other words, it isn't how many but what kind of complaints and the degree of responsibility shown by the company in making an honest effort to eliminate the causes of dissatisfaction, that counts. ${ }^{67}$

In many cases the consumer will not contact the bureau until the seller refuses to adjust his complaint. Although the bureau is effective in resolving consumer complaints arising from "unfortunate misunderstandings," 88 it can do little in situations like Tom's where the company denies all responsibility. The bureau's limitations are illustrated by a leading consumer magazine's account of a buyer who had not received merchandise previously paid for:

[O] ur subscriber wrote the Better Business Bureau which in turn wrote twice to the company in question, but received no reply. The bureau noted that: "Unfortunately the Better Business Bureau cannot compel addressees to answer its communications." 69

Another aspect of the bureau's consumer protection program is the establishment of advertising standards in nearly every sales area. The bureau holds conferences with individual industry groups and administers voluntary advertising codes. $^{70}$ A looseleaf service providing detailed standards in more than fifty different product and service categories is also published. ${ }^{71}$ A committee on each newspaper in screening potentially

66 Upon receipt of the better business bureau report, note 65 supra and accompanying text, the editor made a second telephone call. After insisting that the information he had received could not be helpful to him, he was transferred to the "rug expert" who informed him that the information given could not be supplemented and that he should use his own intelligence in deciding whether to deal with the company. 1964.

67 "Complaints" Alone Don't Tell the Story, 44 The Shield, No. 18, Sept. 15,

68 Serf-Regulation 18. The bureau estimates this type of complaint accounts for "perhaps half of all consumer problems." Ibid.

69 Editor's note to "Don't Be Gypped by Mail-Order Firms," Consumer Bull. March-April, 1964, p. 1.

70 SeLF-Regulation 12-13.

${ }^{71} \mathrm{~A}$ Guide for Retail Advertising and Selling (Association of Better Business Bureaus, Inc.) advertisement on file in Biddle Law Library, University of Pennsylvania; see 45 The Shield, No. 10, May 15, 1965. The National Better Business Bureau also publishes a looseleaf service, "Do's and Don't's in Advertising Copy," see National Better Business Bureau, Report on Operations (1964). 
fraudulent copy ${ }^{72}$ draws suggestions from bureau standards and occationally checks directly with the bureau before running particular advertisements. ${ }^{73}$ Indeed, one Philadelphia newspaper submits "all carpet advertising . . . before publication." " 74 This newspaper, however, does not relinquish its right to make the final judgment. As the paper's retail advertising manager wrote in a memorandum explaining this policy to his staff, "we are guided only by them [better business bureau personnel], and then determine our own policy . . . . This goes for all types of advertising . . . . " 75

As Tom discovered when he read his daily newspaper, advertisements objectionable on their face are still printed ${ }^{76}$ despite the setting of standards and the establishment of committees. Misleading copy is submitted by an advertising representative who "doesn't worry himself about what's in the ad [since] he only wants his commission." 77 It then may be published because of management's conviction that "a newspaper's not a censor" and cannot "suggest how people should write copy." 78 If the bureau's daily local newspaper check reveals such misleading copy, a letter ${ }^{\mathbf{7 9}}$ or an "advertising double check" form is sent to the company running the ad. These communications are not sent to "criticize the advertisers, but merely . . . [to ask] them to recheck and reevaluate their copy when making the same or similar copy usage in the future." 80 Even though cooperation is secured from the advertiser in a great majority of cases, it is "sometimes only after weeks of persuasion and patient negotiation" 81 during which time the harmful advertising appears before the public every day. The bureau will only contact the newspaper that publishes the ad if the company continually refuses to honor bureau requests to have the

72 Interviews With Retail Advertising Managers. The Advertising Acceptability Department of the New York Times declined 18,000 lines of advertising copy in 1962. Address by Vincent Redding, Manager, Advertising Acceptability Department, The New York Times, Sales Conference of Newspaper Advertising Executives Association, July 12-15, 1964. The rejected copy was found either to be misleading, to make unfair competitive statements, or to fail to comply with Times standards of decency and dignity. See New York Times, Standards of Advertising Acceptability 2 (1964). See generally id. at 4-7.

73 Self-Regulation 15; National Better Business Bureau, Report on OpERATIONS (1964).

74 Interoffice memorandum from the retail advertising manager of the Philadelphia Evening Bulletin to his staff, on file in Biddle Law Library, University of Pennsylvania.

75 Ibid.

76 See notes 23-28 supra and accompanying text.

77 Interview With Better Business Bureau Official.

78 Interview With Newspaper Retail Advertising Manager.

79 An advertisement offering the "lowest prices in town" led the bureau to send the company a letter, informing it that its advertisement conflicted with bureau standards. Interview With Better Business Bureau Official.

8043 The Shield, No. 11, June 1, 1963.

81 Nationat Better Business Bureat, Report on Operations (1964). In the National Better Business Bureau's investigation of national advertising, cooperation was secured from the advertisers and their agencies in more than $94 \%$ of the cases where the advertising was adjudged to be misleading. Ibid. 
objectionable material removed. ${ }^{82}$ The newspaper is also not criticized, but is requested to discontinue the advertisement which could not have been printed had bureau standards been followed. ${ }^{83}$

Furthermore misleading advertising practices sometimes are so widespread that the bureau does not even attempt to halt the practice. Grossly exaggerated claims of potential earnings, ${ }^{84}$ representations of substantial savings on items actually sold at retail prices, ${ }^{85}$ "special" sales that run continually, ${ }^{86}$ and low prices offered without suggestion of the limited quantity of the merchandise that can be obtained at that price ${ }^{87}$ are published constantly in newspapers and are defended as "trader's talk" or "puffing." 88

Even newspapers with the most effective procedures for screening advertisements that are false or misleading on their face may be subject to criticism, since in many cases they accept copy without making any attempt to ascertain if the advertiser is in a position to supply the products or services promised. The New York Times, for example, was criticized by a consumer testing magazine for advertising a microscope with magnification of 1200 times for seventeen dollars and fifty cents, when even a cursory investigation would have revealed that well known microscope makers could only offer such high magnification with instruments priced in the range of four to five hundred dollars or more. ${ }^{89}$

82 Interview With Better Business Bureau Official. Another alternative open to the Bureau is to have the case

subjected to the pitiless glare of publicity. Sometimes this may be done in

the Bureau's bulletin which is widely circulated to business executives and to employees. Or it may be made available to printed and broadcast media. .. [A]s a last resort information concerning the offender's activities may be brought to the attention of the proper city, state, or federal law enforcement agency. ...

Your Better Business Bureau.

83 Interview With Better Business Burean Official.

84 E.g., Philadelphia Daily News, June 7, 1965, p. 50, cols. 3-4 (you can earn $\$ 500.00$ a week as a professional dog trainer). But see NEw Yorr Times, STANDards of AdvERTISING AcceptabILITy 5 (1964) (no ads will be accepted for salesmen stating that specific income will be achieved within a given period of time).

85 See 45 The Shield, No. 4, Feb. 15, 1965 (warning that offers of beef at extremely low prices per pound refer to undressed portions, and when the beef is trimmed into usable cuts, the price per pound is boosted to ordinary retail price).

80 "Clearance in August, Clearance in October, Once a Year Sale in November, Sale Every Month." Interview With Better Business Bureau Official; see note 24 supra.

87 Compare Philadelphia Inquirer, June 6, 1965, p. 8 (TV section) (carpet advertisement in which no mention is made of square footage of carpeting offered for price stated), with Inter-office newspaper advertising manager memo, supra note 74 (newspaper adopts better business bureau standard of placing footage available for price on all carpet advertisements).

88 "It would only be 'puffing' if we ran an ad telling people they could make up to $\$ 100,000$ a year working for our paper. I don't make that much, but some of the men working in the front office must. So you can 'make' that much. No one would believe that everyone does." Interview With Newspaper Advertising Manager.

80 Consumer Bull. April, 1962, p. 2. It has been remarked that the New York Times "features all the news that's fit to print, but has no corresponding slogan on the quality of its advertising." Ibid. 
While newspapers refuse to accept any copy in certain fields particularly fraught with the likelihood that the offered item is not available ${ }^{80}$ and will carefully investigate the underlying offer in a few additional questionable classifications, ${ }^{91}$ most advertisements are printed without a preventive check into the company's ability or desire to stand behind its advertisement. ${ }^{92}$ The policy of many newspapers is to publish any advertisement submitted by a company whose name is well known, unless the copy violates newspaper standards by being fraudulent on its face. ${ }^{93}$ In defense of this policy, newspapers argue that "we aren't set up to protect people from buying poor quality merchandise." The publication of many fraudulent advertisements is also rationalized by assuming that the public is sufficiently sophisticated to recognize fraudulent schemes. This is indicated by the remarks of a newspaper advertising manager that, "we run many used car ads, for example, without checking deals. Everyone knows used car dealers are not the epitome of honesty."

While the newspaper can not be expected to make an exhaustive investigation of every advertiser, it should certainly check whenever it has a reasonable suspicion that the dealer is not offering what he advertises. In many cases, this suspicion should be aroused by the nature of the advertisement itself, such as a price so low that it is unlikely that a satisfactory product could be sold for that figure. ${ }^{94}$

Unfortunately when the newspaper does call upon a better business bureau for information about a prospective advertiser, the bureau will disclose, as in the case of consumer inquiries, only the number of consumer complaints registered and the number the company has answered. ${ }^{95}$ The bureau refuses to discuss with the newspaper the type of complaints or the nature of the firm's responses since "that would take all day." 96

In situations involving both advertising and selling abuses, action by appropriate local, state or federal authorities will be requested by the bureau only after all attempts to secure voluntary compliance have been unsuccess-

90 Philadelphia newspapers, for example, will not run advertisements for vending machine schemes. Interview With Better Business Bureau Official. The New York Times will not print advertisements soliciting investments in nonproducing mining or oil property, or in oil royalties. New York TIMES, Standards of Advertising ACCEPTABILITY 4 (1964).

91 One Philadelphia newspaper indicated that it makes each investment or franchise dealer who wishes to advertise fill out a detailed four page form stating the type of contract potential investors must sign and the type of inventory securing their investment. The New York Times also requires certain advertisers to fill out questionnaires. New YoRK TIMES, Standards OF AdVERTISING ACceptability 3 (1964).

92 One of the results of such a policy is that "cheats and swindlers masquerading as mail-order dealers. . have had no difficulty getting their advertising . . . into newspapers . " Editor's note to "Don't Be Gypped by Mail-Order Firms," Consumer Buil., March-April, 1964, pp. 1, 4.

93 Interview With Newspaper Advertising Manager.

94 See 44 The Shield, No. 5, March 1, 1964 (automobile advertised for "only \$49" lacked engine).

95 See notes 65-66 supra and accompanying text.

86 Interview With Better Business Bureau Official. 
ful. ${ }^{97}$ Unfortunately, government authorities are not always in a position to operate effectively because the better business bureaus, in the name of voluntary self-regulation, have opposed and helped defeat consumer protection legislation. ${ }^{88}$

\section{B. Private Attorneys}

Although most attorneys are sympathetic to the problems that face consumers like Tom, they feel that financial considerations make it impractical to help such individuals. ${ }^{99}$ As one New Jersey lawyer explained:

The sad thing is that these people that get cheated often have the legal right to get a judgment against the company. The problem is how to enforce these rights. Since in New Jersey the paperwork for a $\$ 150$ claim is the same as for a $\$ 10,000$ claim I just have to turn people down who have lost small amounts.

In many instances fraudulent operators carefully avoid cheating individuals out of large sums of money because they realize that "no one bilked out of fifty dollars is going to pay a lawyer to get his money back." Thus the only cases lawyers are willing to handle are those brought either by the unusual individual who will pay more than the amount of his claim in order to see justice done, or by those defrauded out of amounts large enough to justify the expenditure for legal fees. The number of consumers having no redress because the amount lost is not commensurate with the attorney's fee constitutes the vast majority. 100

\section{Legal Aid Societies}

The help provided the poor by the legal aid societies has led many to make the statement that "in some cases consumers who have been gypped are better off if they are very poor." Legal aid can afford to represent plaintiffs in cases involving small amounts because, unlike the private attorney, it does not have to make money. Unfortunately however, the societies are often hampered by pathetically small staffs ${ }^{101}$ and inadequate

97 Self-Regulation 18.

98 Kenneth B. Willson, President of the National Better Business Bureau, Inc., stated at Governor Harriman's statewide conference on consumer problems that "the so-called white lie of the dishonest price comparison has reached scandalous proportions and now threatens the believability of all advertising." However, he maintained that businessmen could solve the problem without new legislation. New York World Telegram \& Sun, Oct. 3, 1957, p. 10. See also Donolow Committee Hearings, June 13, 1962, at 591, 605 (testimony of Kenneth Orr, representative of the Pittsburgh Better Business Bureau, opposing any change in consumer credit statutes including the proposal for licensing salesmen). But see Donolow Committee Hearings, May 10, 1962, at 46 (testimony of William D. Henderson, Trade Practice Consultant of the Philadelphia Better Business Bureat).

90 See notes 52-53 sispra and accompanying text.

100 Consensus of Interviews.

101 The Camden County, New Jersey, Legal Aid Society, for example, consists of two part time attorneys, one a recent law school graduate. In Pittsburgh, Pennsylvania, the Society has eight attorneys, but it must also assume the functions of a defender association so that four of these attorneys work only on criminal matters. 
budgets ${ }^{102}$ which severely limit their community service potential. In order to effectively utilize limited resources, the Philadelphia Legal Aid Society generally investigates any group or individual against whom three or more complaints are filed. This program has the merit of halting fraudulent practices before they become widespread and engender additional complaints. ${ }^{103}$

Strong opposition voiced by the organized bar in a few cities to many facets of the legal aid activities has hampered the societies' effectiveness by instilling a fear of being "in competition with private counsel." 104 This has led to the rule that "the Legal Aid Society will not knowingly accept any case for service where the client can pay a fee . . ." 105 and this rule has been implemented by the setting of strict maximum income levels for representation. ${ }^{106}$ This policy has been criticized as unfair because it denies representation to all those defrauded consumers like Tom whose income level is above the maximum set but who are unable to hire an attorney since his fees would be higher than the amount they seek to recover. ${ }^{107}$ Philadelphia's Legal Aid Society remedies this situation in some cases by waiving its maximum income standards in order to represent persons so situated. ${ }^{108}$

The influx of federal funds to cities participating in anti-poverty programs may help to solve some of the problems of legal representation for the poor. Thus a committee of the Philadelphia Bar Association has suggested a plan whereby a consumer advocate will serve as an arm of the poverty program, arguing test cases, protecting the public against fraud, and endeavoring to correct problems through legislation or administrative process. $^{109}$ Such a specific program must be adopted in order to insure that the problem of consumer fraud will not be brushed aside by the mass of other duties which any counsel appointed to aid the poor must perform.

\section{State and Local Government Protection}

\section{A. Retail Sales Legislation}

The kind of practices to which Tom Conwell fell victim were intensified by the tremendous expansion of consumer credit from 1945 to 1965. In this period consumer debt expanded twelve fold reaching its present

102 Consensus of Interviews With Legal Aid Attorneys.

108 Interview With Robert D. Abrahams, Chief Counsel. Abrahams keeps a bulging scrapbook of clippings attesting to the success of this policy.

1041962 PitTsburgh Legal Aid Society ANn. ReP.

1051963 Pittsburgh Legar Am Societr AnN. ReP.

106 For example, a married man without children will not be represented by the Pittsburgh Legal Aid Society if his annual income is greater than $\$ 3,000$. Interview With Pittsburgh Legal Aid Society Personnel.

107 See note 55 supra and accompanying text.

108 Interview With Attorneys for Philadelphia Legal Aid Society.

109 Interview With Robert D. Abrahams, Chief Counsel, Legal Aid Society of Philadelphia. Philadelphia's Legal Aid Society, Bar Association, and Anti-Poverty Action Committee will jointly sponsor this effort when final plans are adopted. Abrahams stated that funds should be available to provide the consumer advocate with an investigatory and secretarial staff. 
eighty billion dollar level while disposable income only tripled. ${ }^{110}$ The commercial banks and finance companies-the primary lenders ${ }^{111}$ - set the stage for defrauding credit buyers like Tom by purchasing commercial paper from dealers whose techniques include:

high finance charges; excessive service charges; investigation fees and so-called settlement fees; . . . misrepresentation with respect to the underlying goods or services; and failure of the sellerlender to disclose fully the terms and conditions of the contract before the buyer's signature is affixed.112

When the consumer sought legal protection, he was informed that "our present laws are limited in scope and applicability. They were not designed for-nor do they apply to-the present and new types of consumer credit transactions." 113 Pennsylvania, for example, found that the only statute of general applicability dealing with interest rates ${ }^{114}$ was its usury statute of 1858,115 which did not cover finance charges added as part of the sales price. ${ }^{116}$ To fill this gap, interested legislators in many states have introduced bills to regulate credit transactions either in all selling fields ${ }^{117}$ or in areas peculiarly associated with abuse, such as automobile sales. ${ }^{118}$ The threat of governmental regulation, ${ }^{119}$ however, brought together powerful business groups which fought any legislation that might interfere with their activities. ${ }^{120}$ This lobby claimed that installment sell-

110 Address by Colston $\mathrm{E}$. Warne, Tenth Annual AFL-CIO National Conference on Community Services, May 20,1965, on file in Biddle Law Library, University of Pennsylvania.

111 Commercial banks are the largest holders of consumer paper, accounting for about $40 \%$ of the total, with sales finance companies holding less than half as much as the banks. Ibid.

112 Donolow Committee Hearings, May 10, 1962, at 102 (statement of William M. Steinbeck, Deputy Secretary of Banking).

113 Donolow Committee Hearings, May 15, 1963, at 20 (statement of Walter Alessandroni, Attorney General of Pennsylvania).

114 See Donolow Committee Hearings, May 10, 1962, at 19 (testimony of David Stahl, Attorney General of Pennsylvania, describing absence of Pennsylvania legislation).

115 Pa. Stat. ANN. tit. 41, §§1-5 (1954).

116 See Equitable Credit \& Discount Co. v. Geier, 342 Pa. 445, 449, 21 A.2d 55, 58 (1941) ; Personal Discount Co. v. Lincoln Tire Co., 67 Pa. D. \& C. 35, 39 (C.P. Philadelphia County 1949).

117 See Note, Retail Instalnent Sales Legislation, 58 CoLUM. L. REv. 854, 856 (1958). See generally Hogan, A Survey of State Retail Installment Sales Legislation, 44 CoRnell L.Q. 38 (1958).

118 See Note, 58 ColuMr. L. Rev. 854, 856 (1958).

110 "People don't like to be subjected to governmental regulation and we don't like being blamed for regulation." Address by Anthony G. Felix, Jr., Esq., 1963 Lending Conference, Pennsylvania Bankers Association, November 21, 1963 " [hereinafter cited as Pennsylvania Bankers Association Address]. In this address, Mr. Felix, who is Senior Vice President and Secretary of the First Pennsylvania Banking and Trust Company, explained to the Bankers Association why one of its committees had drafted the Pennsylvania Home Improvement Finance Act.

120 Cf. New York World Telegram \& Sun, Oct. 3, 1957, p. 10 (opposition to proposed advertising laws from Chamber of Commerce, State Council of Retail Merchants, Better Business Bureau and National Retail Jewelers Association). 
ing would be depressed, and the unscrupulous would circumvent the new laws, leaving the onus of regulation on responsible businessmen. ${ }^{121}$

The strength of this opposition is demonstrated by the problems which the proponents of consumer protection legislation have encountered in Pennsylvania. In the late 1940 's, when credit sales of automobiles were still in their infancy and opposition to consumer credit legislation had not as yet crystallized, ${ }^{122}$ the Pennsylvania legislature passed the Motor Vehicle Sales Finance Act ${ }^{123}$ which denied "holder in due course" protection to holders of automobile paper. ${ }^{124}$ The act not only required installment sellers and finance companies ${ }^{125}$ to be licensed but also set down requirements for the content of contracts. ${ }^{128}$

In 1962 the Pennsylvania Senate Banking Committee held hearings on consumer credit practices, which emphasized the need for similar legislation covering all types of retail installment sales. ${ }^{127}$ When passage of either the senate "all goods" bill produced by these hearings ${ }^{128}$ or house home improvement legislation ${ }^{229}$ became "not only inevitable but imminent," 130 the Pennsylvania Bankers' Association decided to change its tactic of "quiet opposition" 131 to bills that were "for some reason not entirely satisfactory to banks." 132 Although it realized that the need for "all-goods" legislation was unmistakable, ${ }^{133}$ the Pennsylvania Bankers Association drafted a bill providing safeguards only for installment purchases of home improvements. This bill was substituted for the pending legislation and was passed. ${ }^{134}$

The resulting statute, the Home Improvement Finance Act, ${ }^{135}$ not only fails to meet the admitted need for protection in all retail sales but also leaves consumers like Tom completely unprotected. The act does not specify what constitutes a "home improvement" except for the statement

121 Interviews With Bank and Finance Company Officials; see Hogan, supra note 117 , at 73 .

122 "If the bill came up today, we would oppose some of its major provisions vigorously and I'm certain it wouldn't pass." Interview With Bank Counsel.

123 PA. Stat. Ans. tit. 69, $\$$ 601-37 (Supp. 1964).

124 PA. Stat. ANN. tit. 69, $\$ 615$ (g) (Supp. 1964).

125 Pa. Stat. AnN. tit. 69, §604 (Supp. 1964).

126 Pa. Stat. AnN. tit. 69, §§614-15 (Supp. 1964).

127 Donolow Committee Hearings, May 10, 1962, May 25, 1962, June 13, 1962. After these hearings ended, Senator Benjamin H. Donolow, Chairman of the Committee, introduced a bill, Pa. S. 580, Sess. of 1963, and an additional hearing was held on May 15, 1963, to enable interested parties to express their opinions on the proposed legislation.

$128 \mathrm{~Pa}$. S. 580, Sess. of 1963.

$129 \mathrm{~Pa}$. H. 120, Sess. of 1963.

130 Pennsylvania Bankers Association Address 2.

131 Consensus of Interviews With a Pennsylvania State Senator, Counsel to

Senate Investigating Committee on Consumer Credit, and Deputy Attorney General. 132 Pennsylvania Bankers Association Address 2.

133 Ibid.

134 Home Improvement Finance Act, PA. Stat. ANw. tit. 73, $\S 500-101$ to -602 (Supp. 1964).

135 Ibid. 
that it does not cover "an appliance designed to be free-standing and not built into and permanently affixed as an integral part of the structure." 136 Even if carpeting bought in large quantities and specifically made for areas in a home could be classified as a home improvement, ${ }^{137}$ Tom would remain unprotected since his purchase falls below the act's 300 dollar minimum. ${ }^{138}$ The ineffectiveness of this legislative effort should not have been unexpected, however, since, as one commentator has stated, "the result [of following financial interests' advice] is from the consumer's point of view rather like what might emerge if a committee of dogs were employed to draft a protective ordinance for cats." 139

An all-goods act substantially the same as that proposed two years before was introduced in the 1965 legislative session. ${ }^{140}$ The proposed act's chance of passage was adequately assessed by counsel for the 1962 hearings when he said: "I didn't even pick up a copy of this bill since I know it won't pass." Even the chairman of the committee to which the bill was referred is refusing to hold hearings because of the great opposition to the bill by business interests in his district. ${ }^{\mathbf{1 4 1}}$

The chief impediment to passage of such legislation is familiar. It appears that although banks "will tell you they are in favor of legislation to protect the consumers, when the time comes, they have the votes to defeat it." 142 Financial interests also are criticized because they merely reject bills in their entirety rather than discuss specific provisions that they oppose. ${ }^{143}$

The opposition to all-goods legislation manifested in Pennsylvania has been overcome in many states. By 1965 twenty-eight states had succeeded in enacting such legislation. ${ }^{144}$ However, the statutes passed are

136 PA. Stat. ANN. tit. 73, §500-102(10) (Supp. 1964).

137 Suggestion of Deputy Attorney General. A Pennsylvania state senator, however, predicted that courts would not interpret the act as covering carpeting.

138 Pa. Stat. AnN. tit. 73, §500-102(11) (Supp. 1964).

139 Gilmore, American Chattel Security Devices, 2 Bus. L. REv. 65, 70 (1955). $140 \mathrm{~Pa}$. S. 323, Sess. of 1965.

141 Interview With Pennsylvania State Senator Rowland B. Mahany, Chairman of the Senate Banking Committee. The act has succeeded in passing the Pennsylvania House of Representatives, but only after it had been amended 102 times. Philadelphia Evening Bulletin, Dec. 16, 1965, p. 25, col. 1. The senate adjourned without passing the bill.

142 Interview With Deputy Attorney General. This view was echoed in many other interviews including those with legal aid and finance company counsel.

143 Interview With Pennsylvania State Senator.

144 The following statutes covering all goods have been enacted: Alaska STAT. $\$ \S 45.10 .010-.230$ (Supp. 1962) ; Cal. CIv. Code \$§ 1801-1812.9; Colo. Rev. Stat. ANN. $\$ \$ 121-2-1$ to -10 (1962) ; Conn. GEn. Stat. Rev. $\$ \$ 42-83$ to -100 (1962); DeL. Code AnN. tit. 6, $\$ \$ 4301-50$ (Supp. 1964); Fla. Stat. ANN. $\$ \$ 520.30-.42$ (1962); HawaII REv. LAwS $\$ \$ 201 A-1$ to -33 (Supp. 1963); IDAHo CODE ANN. \$ 64-806 (Supp. 1965); Ir.. ANN. Stat. ch. 1211/2, \$\$223-53 (Smith-Hurd 1960); Ind. AnN. Stat. \$\$ 58-901 to -945 (1961) ; Kan. Gen. Stat. AnN. \$\$16-501 to -514 (1964); Ky. Rev. Stat. ANN. \$\$ 371.210-.990 (1963) ; MD. ANN. Code art. 83, $\$ \$ 128-53$ (1957) ; MAss. Gen. Laws Ann. ch. 255, \$\$11-13H (1956); Mo. AnN. Stat. \$\$ 408.250-.370 (Supp. 1964) ; Mont. Rev. Codes ANN. \$\$74-601 to -612 (1962); Neb. Laws 1965, L.B. No. 283 ; Nev. Laws 1965, A.B. No. 440; N.J. StAT. ANN. \$\$17:16C-1 to -61 (1963); 
characterized by wide differences in coverage ${ }^{145}$ and content; ${ }^{146}$ few are extensive enough to provide full protection for the consumer. A number of specific provisions must be included in any such legislation if it is to perform its function adequately. The types of provisions necessary are the subject of the following discussion.

\section{Holder in Due Course}

The factor singled out by the great majority of those interviewed for this study as the largest problem in the consumer fraud area-"the mask behind which fraud hides" ${ }^{147}$-is the ability of financial agencies, absent regulation in retail sales acts, to purchase installment contracts free from responsibility for fraudulent practices perpetrated by dealers. Once Tom's note was in the hands of the finance company, ${ }^{148}$ he was required to pay for his carpets, although they were defective and the company would not repair them. He similarly would be obliged to pay if the carpet company had gone out of business after defrauding him or had no corporate assets and was therefore judgment proof.

The Uniform Commercial Code protects a financial institution that buys negotiable consumer paper as a holder in due course, ${ }^{148}$ unless the consumer can prove: (1) that the holder had notice that . . . [the in-

N.M. Laws 1965 , ch. 258 ; N.Y. Pers. Prop. Law $\$ \$ 401-19 ;$ N.D. Cent. Code $\S \S 51-13-01$ to 108 (1960); OHIo REv. Code ANN. \$\$1317.01-.99 (Page 1962); ORE. Rev. Stat. \$\$ 83.010-.190 (Supp. 1963); TeNN. Code ANN. \$\$ 47-11-101 to -110 (1964); UTah Code ANN. \$15-1-2a (1962); VT. STat. ANN. tit. 9, \$\$ 2401-09 (Supp. 1963); 'WAst. Rev. Code ANN. \$\$ 63.14.010-.920 (Supp. 1964).

Twenty-six automobile finance acts have been enacted: Ariz. Rev. Stat. Ann. $\$ \$ 44-281$ to -295 (Supp. 1964) ; Cal. Crv. Code $\$ \$ 2981-84.3$; Colo. Rev. Stat. ANN. $\S \S 13-16-1$ to -10 (1953); D.C. CoDE ANN. $\$ \$ 40-901$ to -910 (1961) ; DEL. CoDE ANN. tit. 5, $\$ 2901-11$ (Supp. 1964); Fla. Stat. ANN. $\$ \$ 520.01-.13$ (1962); Iowa CodE AnN. \$\$ 322.1-.16 (1949); KY. Rev. Stat. AnN. \$\$ 190.090-.990 (1963) ; LA. Rev. Stat. AnN. \$\$ 6:951-64 (Supp. 1964); ME. Rev. Stat. AnN. ch. 321, \$3401 to ch. 327 , 3523 (1964); Mass. GEN. Laws ANN. ch. 255B, \$\$ 1-24 (Supp. 1964) ; Mrch. Comp. Laws $\$ \S 492.101-140$ (Supp. 1961); MrNn. STAT. ANN. $\$ \$ 168.66-.77$ ' $(1960)$; Miss. Code ANN. $\$ \S 8075-01$ to -24 (Supp. 1964); Mo. AnN. Star. $\$ \S 365.010-160$ (Supp. 1964); N.H. Rev. STAT. ANN. \$\$ 361-A:1-:12 (Supp. 1963) ; N.M. STAT. ANN. $\$ \$ 50-15-1$ to -12 (1962); N.Y. PERS. Prop. LAW $\$ \$ 301-12$; N.C. GEN. STAT. $\$ \$ 20-285$ to -308 (Supp. 1963)'; ORE. REv. STAT. \$\$ 83.510-.990 (Supp. 1963) ; PA. STAt. ANN. tit. 69, $\$ \S 601-37$ (Supp. 1964); S.D. Cone $\$ \S 6.04 C 01-15$ (Supp. 1960); Tex. Rev. Civ. Stat. ANn. art. 5074a (1962); Vt. Stat. ANN. tit. 9, \$ 2351-61 (Supp. 1963); VA. Code ANN. §§ 46.1-545 to -550 (1958); WIS. STAT. §218.01 (1963). New Jersey and Pennsylvania have home finance acts: N.J. STAt. ANs. \$§ 17:16C63 to -94 (1963) ; PA. Stat. AnN. tit. 73, \$\$ 500-101 to -602 (Supp. 1964).

For a detailed analysis of the provisions of each of these statutes see generally CuRraN, TRENDS in Consumer CREDIt Legislatron (1965); CCH Installment CreDit GuIDE.

145 See Note, 58 Colum. L. Rev. 854, 862-64 (1958).

148 See id. at 866-85.

147 Interview With New Jersey Municipal Judge.

148 The process by which the finance company acquired Tom's note is described in Note, Consumer Sales Financing: Placing the Risk for Defective Goods, 102 U. PA. L. REv. 782, 783 (1952).

149 UNIFORM COMMERCIAL CoDE $\$ \$ 3-302,3-305$; see UNIFORM NEGOTIABLE INSTRUMENTS LAW $\$ \S 52,57$. 
strument] is overdue or has been dishonored or of any defense against or claim to it on the part of any person"; ${ }^{150}$ or (2) that the consumer signed the note under such misrepresentation that he had "neither knowledge nor reasonable opportunity to obtain knowledge of its character or its essential terms." 151

Every financing agency interviewed claimed that it conducted a detailed check of each dealer before purchasing his consumer paper and also spot checked customers to ascertain if they were receiving the products or services for which they had contracted. ${ }^{152}$ Each admitted, however, that many other agencies were taking advantage of the difficulty of proving dealer fraud by purchasing consumer paper either with actual knowledge of an underlying fraudulent sale or under conditions where reasonable inquiry would apprise them of this fact. ${ }^{153}$ Realizing that it is almost impossible for a defrauded consumer to prove that a financial institution had actual notice of his transaction with the dealer, courts have recently been withdrawing the holder in due course protection from financial institutions which "should have known" the underlying transaction was fraudulent. Some courts have thus placed responsibility on financial agencies that become completely intertwined with the dealer whose paper they purchase. For example, in Westfield Inv. Co. v. Fellers, ${ }^{154}$ the court held that a finance company "became so inextricably a part of the original transaction with the purchaser that it could not thereafter stand aloof in the role of a holder in due course in good faith" 155 when it had knowledge of the general difficulties existing in food freezer sales, required the dealer to use forms it prepared, and insisted that the resulting notes could only be negotiated to the finance company.

Courts are also restricting holder in due course protection in areas where banks and finance companies are adopting a "see no evil" stance. Often in these cases discount rates are marked down significantly, and a dealer might receive only fifty percent for his paper. "The suspicion must be in such cases either that the vending company has no intention of furnishing what it has promised the consumer, or has vastly overpriced the item sold." ${ }^{156}$ Thus, in Norman v. World Wide Distrib., Inc., ${ }^{157}$ the court

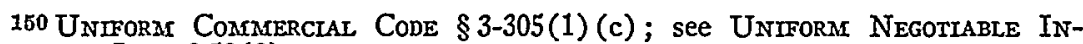
STRUARENTS LAW § $52(2)$.

151 UntForm CoMmarcial Code \$3-305(2)(c); see UnIform Negotiable INSTRUMENTS LAW § 55 .

152 Spot checking is not always effective, since some salesmen may tell the purchaser that in order to facilitate a better credit arrangement, the salesmen must tell the finance company that an unfinished job has been completed to the purchaser's satisfaction. Interview With Finance Company Officials. being."

153 As stated by a bank official, they are "financing where they have no right

15474 N.J. Super. 575, 181 A.2d 809 (L. 1962).

$155 I d$. at 591,181 A.2d at 818 .

156 Donolow Committee Hearings, May 10, 1962, at 42 (testimony of Robert

D. Abrahams, Chief Counsel, Legal Aid Society of Philadelphia).

157202 Pa. Super. 53, 195 A.2d 115 (1963). 
held that a finance company which discounted a 1,079 dollar note due in three days for $\$ 831$, with knowledge that the sale was on a referral basis and that the dealer had changed its name three times during the preceeding year, "was bound to inquire further into the operation of the seller of these notes, and having made no inquiry, it is held as though it had knowledge of all that inquiry would have revealed." 158 The effectiveness of cases limiting the holder in due course defense is dulled by ignorance of the law on the part of attorneys. An attorney for a large finance company stated that he used the holder in due course doctrine

to scare away lawyers. Every time they have a claim against you, you tell them that they'll have to sue the dealer since you are protected as a holder in due course. Lawyers generally don't even know that the protection was taken away by the Motor Vehicle Sales Finance Act, and you can count the ones that know about the Norman case on your fingers.

On the other hand, action by knowledgeable attorneys has not led to decisions clarifying the restrictions of the doctrine, but has only engendered private settlements with banks and finance companies. A finance company attorney remarked that "to say that banks and finance companies will bend over backwards to settle claims rather than go to court is an understatement." Banking counsel charged that courts are straining the law to hold against banks and finance companies and agreed that "the time is definitely not ripe for any more test cases on the scope of the [holder in due course] doctrine."

While cases narrowing the scope of the holder in due course protection do provide some aid to the innocent consumer, these decisions leave unaltered the practices creating the need for defenses against the financial institution, conditions which will be corrected only by consumer protection legislation. ${ }^{169}$ Some state retail sales acts completely remove consumer installment notes from the area of negotiability and forbid clauses whereby the consumer waives all defenses against a holder for value of the note. ${ }^{180}$ A compromise between this step and complete noninterference with the holder in due course doctrine has been adopted by other states, which allow the consumer a short period of time to complain to the finance company about the underlying transaction, after which time the financial institution assumes holder in due course protection. ${ }^{161}$ Under this statutory provision, which is included in Pennsylvania's Home Improvement Finance Act ${ }^{162}$

$158 \mathrm{Id}$. at 59, $195 \mathrm{~A} .2 \mathrm{~d}$ at 118 . For additional cases and discussion see Hogan, supra note 117, at 66 n.147; Note, 102 U. PA. L. REv. 782, 789-91 (1952).

159 Id. at 790-91.

160 See, e.g., Mo. Ann. Code art. 83, §147 (1957) ; Mass. Gen. Laws Ann. ch. $255, \$ 12 \mathrm{C}$ (Supp. 1964).

161 See, e.g., CAL. CIv. Code $\$ 1804.2$ (fifteen days' notice); Del. Cope ANN. tit. 6, § 4312 (Supp. 1964) (fifteen days' notice) ; N.Y. PERS. Prop. LAW § 403(1)-3(a) (ten days' notice).

162 Pa. Stat. Ann. tit. 73, §500-208 (Supp. 1964) (fifteen days' notice). 
and the proposed "all-goods" act, ${ }^{163}$ Tom would have received a form from the finance company stating in large capital letters that he should notify the finance company within ten days, (fifteen days in some statutes ${ }^{164}$ ) if the accompanying written statement of his contract with the carpet company was not "correct in every respect" or "if the goods or services . . . have not already been delivered or performed as you agreed to." 165 Even though the consumer is given this period to complain before the finance company is able to shut the "holder in due course" door on him, the finance companies have not objected to this system. The reason, as stated by one of their attorneys, is:

The courts have been looking for ways to take the holder in due course protection away from finance companies. But here's a way to make the finance company's position invulnerable after the complaining period has passed. And the roof never leaks before this time has been long gone anyway.

Indeed, the Pennsylvania Bankers Association included a five day notice provision-that eventually was increased to fifteen by the legislature ${ }^{168}$-in the Home Improvement bill it drafted. ${ }^{167}$

Under any system in which the financing agency can purchase installment notes free of consumer defenses or can assume this position a short time after a contract is signed, the risk of dealer fraud rests squarely with the consumer. ${ }^{188}$ Although it is true that the buyer chose to purchase from the dealer who defrauded him, this fact should not be determinative in deciding where the burden should lie, for it must be noted that the financing agency selected this dealer before it bought his paper. ${ }^{169}$ Furthermore, the financing agency has facilities that the consumer lacks, enabling it to investigate the dealer's reliability and to make certain that his products, services and sales techniques are not fraudulent or misleading. The agency can also protect itself by dealing on a full recourse basis which would require the dealer to be liable to it for buyer defaults by executing a repurchase agreement, binding the dealer to buy back repossessed merchandise or by requiring the dealer to set aside sufficient funds to protect himself against any contingencies. ${ }^{170}$

Another reason for shifting the risk of dealer fraud from the consumer appears from a consideration of which party is better able to bear the risk. A finance company which loses money on a particular transaction with a

$163 \mathrm{~Pa}$. S. 323, Sess. of $1965, \S 13$ (a)-(b) (1) (ten days' notice).

164 See note 161 supra.

$105 \mathrm{~Pa}$. S. 323, Sess. of $1965, \S 13$ (b) (1).

166 The Installment Credit Committee of the Pennsylvania Bankers Association originally recommended a five-day period. The period was lengthened to ten days when the bill was submitted to the legislators, and was finally increased to fifteen days "by others." Pennsylvania Bankers Association Address 3.

167 See notes 128-134 sipra and accompanying text.

108 See Hogan, $A$ Survey of State Retail Instalment Sales Legislation, 44 CORNEIL L.Q. 38, 66 (1958).

169 Ibid.

170 See Note, 102 U. PA. I. REv. 782, 791-93 (1952). 
dealer can recoup the loss in subsequent transactions. The innocent consumer, on the other hand, may find himself bankrupt if defrauded by a dealer in a single transaction. The argument made by banks and finance companies that the removal of holder in due course protection "would put them out of business" has proved a spurious one. ${ }^{171}$ Notes signed on the purchase of motor vehicles have been unprotected since 1947 in Pennsylvania, ${ }^{172}$ yet the same companies that make the argument continue to finance automobile sales in great numbers. Furthermore, finance companies operate successfully in Massachusetts ${ }^{173}$ and Maryland ${ }^{174}$ which have removed holder in due course protection from all sales. Counsel for a large bank admitted candidly that: "While I would fight the change, it wouldn't be as terrible a thing as many banks will tell you. We check our dealers carefully and only the marginal finance companies that don't would be hurt." Thus, it seems that shifting the risk of fraud to finance companies would not only make it more difficult for fraudulent dealers to operate, but would also result in the elimination of finance companies whose failure to check on dealers has made fraudulent practices possible.

\section{Confession of Judgment}

Perhaps the most objectionable practice in consumer credit is that of requiring the consumer who buys on credit to sign an authorization of entry of confession of judgment at the time he makes his purchase. Tom discovered to his dismay that he had authorized the finance company to record a judgment on his property immediately after purchase. ${ }^{175}$ As soon as he missed a monthly payment, the entire unpaid balance became due and "any . . . attorney or any court" was empowered to obtain a levy on his property without notifying him. ${ }^{178} \mathrm{He}$ also expressly waived any "stay or exemption laws now in force or hereafter enacted." 177

This system does not provide the consumer with any opportunity to present defenses before execution is issued on the judgment. 178 If the note

171 See $i d$. at 796.

172 Pa. Stat. ANn. tit. 69, §615(g) (Supp. 1964).

173 Mass. Gen. Laws ANn. ch. 255, § 12C (Supp. 1964).

174 Md. ANN. Code art. 83, § 147 (1957).

175 See notes 49-50 supra and accompanying text.

176 Installment Sale Contract (for use in Pennsylvania for goods other than motor vehicles), on file in Biddle Law Library, University of Pennsylvania. If Tom wished to save his real estate or household furnishings after being delinquent on a payment, he would have had to pay the entire unpaid balance, an "attorney's fee" of $18 \%$ of the balance, and a "late charge" of $5 \%$. Ibid.

177 Ibid.

178 The process, as described by Philadelphia's District Attorney, James C. Crumlish, Jr. is as follows:

There is a judgment note signed and it is processed and it is immediately recorded. There arises some complaint as a result of the work not having been done satisfactorily. So, the reaction of the consumer, which is a quite natural one, is that: "I won't make my installments until you satisfactorily adjust my complaint." And before he knows it, there has been an execution on the note and his house is about to be sold from under him.

Donolow Committee Hearings, May 10, 1962, at 145. 
has been negotiated, its holder may be in an invulnerable position in any case. But even if defenses are available and there is truth to a finance company attorney's statement that after execution "anyone with any type of defense can open a judgment," most people would certainly be unwilling to pay approximately 300 dollars ${ }^{179}$ "to unravel something which should have been straightened out in the first instance when the complaint was originally made." 180

Financial interests vigorously support the system since it "saves us attorneys' fees." 181 They indicate that there are no complaints to file, no defenses to overcome and no chance that the court might decide the money is not due.

Although some states have outlawed confession of judgment in their retail sales acts, ${ }^{182}$ the practice is so entrenched in Pennsylvania that Philadelphia's District Attorney James C. Crumlish termed it a "radical suggestion . . . to consider that judgment notes should not be recorded until such time as the defendant has had an opportunity to meet the complaint." 183

As in the case of holder in due course legislation, financing agencies complain that restrictions on confession of judgment clauses will destroy their businesses. Yet in states where new laws have been enacted the agencies continue to prosper.

\section{Licensing}

The requirement that vendors and holders of retail installment contracts be licensed is another effective method of controlling objectionable consumer credit practices. The head of the New York State Attorney General's fraud bureau has stated, "if they don't behave, we can take their licenses away and put them out of business." Well enforced licensing provisions have also been effective in ridding other states of fly by night vendors. ${ }^{184}$ The broad coverage of the proposed Pennsylvania "all-goods" act provides for licensing of anyone "either as principal, solicitor, agent or broker in the negotiation, purchasing, or making of a collection on retail installment contracts . . . 185 Only employees working inside a regular place of business are exempted. ${ }^{186}$

179 The Philadelphia Bar Association minimum fee for opening a judgment is $\$ 150$, and an attorney in a neighborhood law office estimated that the average fee charged for handling such a case is more than $\$ 300$.

180 Donolow Committee Hearings, May 10, 1962, at 145 (testimony of Philadelphia's District Attorney James C. Crumlish, Jr.).

181 Interview With Finance Company Attorney.

182 See, e.g., Cad. Crv. Code \$ 1804.1(c); Conn. Gen. Stat. Rev. § $42-88$ (1962); Md. AnN. Code art. 83, §130(b) (1957); N.J. Stat. ANN. §17:16C-37 (1963); N.Y. PERS. PRop. LAw $\$ 403$ (3) (c).

183 Donolow Committee Hearings, May 10, 1962, at 144.

184 Interview With Chief of New Jersey Consumer Credit Division of Department of Banking and Insurance.

$185 \mathrm{~Pa}$. S. 323, Sess. of $1965, \S 3$.

186 Ibid. 
Many interests oppose the Pennsylvania bill solely because of the restrictions imposed by the licensing provisions, often on the theories that licensing entails unnecessary governmental intervention and that "businessmen have the ability to keep their own good house in order . . . ." 187 The most controversial section of the bill is that requiring licensing of all "outside salesmen." This provision is sometimes opposed because of the erroneous impression that all employees of a dealer must be licensed. ${ }^{188}$ The chairman of the committee to which the bill was referred, for example, stated that every store owner in his district, whether or not conversant with the actual terms of the section, had contacted him to complain about it. ${ }^{189}$ Yet, this licensing provision is called necessary for effective consumer protection. "As it stands now," a magistrate pointed out, "the homeowner may not know with whom he is dealing and has no address to go to if the work is done wrong." Pennsylvania's attorney general favors individual licensing to prevent violators "from hiding behind a multitude of corporations and fictitious names." 190

Modification appears to be necessary to harmonize the bill's provisions with sections in other states ${ }^{191}$ exempting banks which already are closely regulated by other state and federal statutes. ${ }^{192}$ In addition, the requirement that finance agencies must be organized under the Pennsylvania Business Corporation Law ${ }^{193}$ places an unnecessary restriction on out of state finance companies.

For licensing to achieve optimum effectiveness, the powers granted to the agency responsible for supervising licensing must be selected with a view to providing procedures directly aimed at alleviating existing fraudulent practices. Even though an agency may have the authority to hold hearings and subpoena records, it may be handicapped by the restricted conditions under which it can conduct investigations. In Maryland, the commissioner may act only after a written complaint has been filed by a

187 Donolow Committee Hearings, June 13, 1962, at 605 (testimony of Kenneth Orr, Better Business Bureau of Pittsburgh).

188 See Donolow Committee Hearings, May 15, 1963, at 33 (testimony of John Means, Managing Director of the Pennsylvania Retailers Association); Interview With Banking Official. The Chief of the Consumer Credit Division of the New Jersey Bureau of Banking stated that one of the chief problems faced in passing a bill licensing salesmen is convincing businessmen that all of their secretaries and janitors will not have to be licensed.

189 Interview With Pennsylvania State Senator Rowland B. Mahany.

180 Donolow Committee Hearings, May 15, 1963, at 22 (statement of Walter Alessandroni). A similar view was expressed by the Chief of the Ohio Attorney General's Consumer Frauds and Crimes Section in a memorandum on file in Biddle Law Library, University of Pennsylvania: "Were the state to pass a law requiring all who engage in door-to-door sales and solicitations to register with local law enforcement officials, notice of their operations would be gained." (1963).

191 See, e.g., MD. Ann. Code art. 83, §154 (1957) ; N.J. Stat. Ann. § 17:16C-2

102 Memorandum on the Proposed Retail Installment Sales Act and the Pennsylvania Usury Act, on file in Biddle Law Library, University of Pennsylvania. This memorandum was sent from a finance company counsel to the chairman of the state banking committee.

$193 \mathrm{~Pa}$. S. 323, Sess. of $1965, \S 5(\mathrm{a})$. 
consumer; ${ }^{104}$ in New Jersey he must have "reasonable cause to believe that any licensee, or any other person, has violated any of the provisions" of the act. ${ }^{195}$ In contrast, the sponsors of the Pennsylvania "all-goods" act proposed that the secretary of banking have power "at any time [to] investigate the business, affairs and activities and examine books . . . " 196 This ability to spot check companies periodically would be a most effective way of insuring compliance with the act. The practice followed in many states of issuing a license simply on the basis of facts which a prospective licensee states in an application form is not sufficient to apprise the agency that the applicant may have fraudulently conducted business in other states or that he may presently be unable to deliver the goods which he offers.

The need for licensing provisions which can be administered by a specific agency is demonstrated by an investigation of the unsuccessful results that occur when consumer protection depends on enforcement by county district attorneys. Local law enforcement authorities have numerous criminal statutes to enforce and can devote only limited time to retail installment legislation. ${ }^{197}$ The Pennsylvania Home Improvement Finance Act, for example, gave the attorney general or district attorney of each county power to initiate court action to restrain violation. ${ }^{198}$ Even though the Pennsylvania Bankers Association hoped that the latter section would "protect the small consumer by keeping an unscrupulous contractor from cloing business," 199 a member of the drafting committee asserted that, so far as he knew, "no restraining order had been sought under the act." On the other hand, the New Jersey Retail Installment Sales Act ${ }^{200}$ gives the consumer credit division of the department of banking and insurance the power not only to revoke or suspend licenses ${ }^{201}$ but also to sue for and collect the penalties provided for violation of any of the act's provisions. ${ }^{202}$

\section{4. "Cooling Off" Period}

Another protective measure aimed at aiding consumers who are victims of high pressure sales techniques was enacted in Pennsylvania's Home Improvement Finance Act. This act requires that a "cooling off" period provision which would permit the purchaser to rescind the sale before five P.M. on the next business day after he has signed be placed in every con-

194 MD. ANN. CoDE art. 83, § 162(a) (1957).

105 N.J. Stat. ANN. § $17: 16 \mathrm{C}-15$ (1963).

$196 \mathrm{~Pa}$. S. 323, Sess. of $1965, \S 10$ (a). A similar section appears in the Motor Vehicle Sales Finance Act, PA. STAт. ANN. tit. 69, §611 (Supp. 1964).

107 See notes 259-261 infra and accompanying text.

198 PA. Stat. Ann. tit. 73, § 500-502 (Supp. 1964).

190 Pennsylvania Bankers Association Address 3.

200 N.J. Stat. ANN. \$17:16C-1 to -61 (1963).

201 N.J. Stat. Ann. $\$ 17: 16 C-11$ (1963).

202 N.J. STAT. Ann. \$ $17: 16 C-56$ (1963). 
tract, subject only to liquidated damage provisions, ${ }^{203}$ limited by the act to ten percent of the cash price. ${ }^{204}$ This section was not included in the bill as originally drafted by the Pennsylvania Bankers Association, ${ }^{205}$ some of whose members vehemently opposed it as "against human nature. It is fundamentally wrong to let the buyer out once the seller has built up his product and then closes the deal. Things just aren't sold like that in the real world." 206 It was pointed out that any purchaser who does not wish to pay can cancel a contract, even "if the sale was made in good faith and everything was clean," thus operating to hurt the legitimate businessman. ${ }^{207}$

Those who sponsored the "cooling off" clause conceive of it as a necessary protection for consumers "who have been pressured into overbuying or buying what they do not want by a clever salesman. Too often, the salesman makes vast oral promises which do not appear in the contract. Sometimes, the real terms of the purchase are not disclosed . . . ."208

The files of the frauds division of the Philadelphia district attorney's office ${ }^{209}$ are replete with complaints from consumers who have had requests for cancellation refused, although made only hours after signing. One finance company counsel has said that "they [dealers] may give him a hard time, but he can always get out of it." The "hard time," however, has been known to cost the consumer hundreds of dollars. ${ }^{210}$

While high pressure salesmen would be greatly handicapped by a cooling off period, legitimate business should not be affected. Many businesses, even without legal compulsion, allow customers to cancel without penalty and even accept goods returned a reasonable time after delivery. ${ }^{211}$

The suggestion which appears to balance most effectively the interest of consumers in rescinding hasty purchases and the businessman's interest in finalizing a sale is the forty-eight hour "cooling off" period proposed by the chief counsel of the Philadelphia Legal Aid Society. ${ }^{212}$ The company's

203 PA. Stat. ANN. tit. 73, § 500-202(c) (4) (Supp. 1964).

204 PA. Stat. ANN. tit. 73, § 500-206(f) (Supp. 1964).

205 The section was "inserted by the legislators sponsoring the legislation or as a result of views expressed by them." Pennsylvania Bankers Association Address 3. 206 Interview With Bank Counsel.

207 Donolow Committee Hearings, June 13, 1962, at 610 (testimony of Kenneth Orr, Better Business Bureau of Pittsburgh).

208 Donolow Committee Hearings, May 10, 1962, at 39 (testimony of Robert D. Abrahams, Chief Counsel, Legal Aid Society of Philadelphia).

209 See note 304 infra.

210 In one case the consumer was forced to pay $\$ 175$ and in another $\$ 90$ in order to cancel. Fraud Division Files.

211 Better Business Bureau, I Want My Money Back!, on file in Biddle Law Library, University of Pennsylvania.

212 Donolow Committee Hearings, May 10, 1962, at 39 (testimony of Robert $D$. Abrahams, Chief Counsel, Legal Aid Society of Philadelphia). Longer cooling off periods have been suggested. A finance company president suggested a seven-day period if shortly thereafter his company could then gain holder in due course protection. A provision for a seven-day period was recently introduced in the California legislature. California Consumer Counsel News Exchange, Feb. 18, 1965, p. 4. 
actual expenses would be defrayed by the consumer's paying a small cancellation fee of about one percent of the purchase price. ${ }^{213}$

\section{Disclosure}

All retail installment legislation contains provisions to insure full disclosure of the terms of the agreement to the buyer. ${ }^{214}$ Those provisions which the state feels are particularly important, such as requesting the buyer to keep a copy of the contract, are required to be printed in each contract in large bold type. ${ }^{215}$ Statutes require that the buyer receive a copy of the written contract, ${ }^{216}$ and over half of the statutes prohibit the signing of contracts containing blank spaces. ${ }^{217}$ Provisions also require a detailed itemization of the charges including a statement of the total time sale price to the buyer. ${ }^{218}$ Still other sections prevent the buyer from waiving the protection of the act. ${ }^{219}$

Regulation of financing charges provided for in most retail sales acts, ${ }^{220}$ is necessary in consumer protection legislation since

the difference . . . between the actual, let's say, cash price of an article and the total price charged by a seller, if it is to be repaid on time payments, is not [otherwise] regulated. It is not considered to be interest and the courts have said it is not covered by the general and particular laws [governing usury and loan company rates]..$^{221}$

213 Donolow Committee Hearings, May 10, 1962, at 39 (testimony of Robert D. Abrahams, Chief Counsel, Legal Aid Society of Philadelphia).

214 Note, 58 Colum. L. Rev. 854, 866-67 (1958). A number of states deal with this problem exclusively in their statutes. Id. at $866 \mathrm{n} .89$.

215 E.g., Cax. Civ. Code § 1803.2; Conn. Gen. Stat. Rev. § 42-84(c) (3) (1962); Dec. Code AnN. tit. 6, § 4304 (c) (Supp. 1964); Irt. ANN. Stat. ch. 1211/2, § 224 (b) (Smith-Hurd 1960); N.Y. Pers. Prop. LAw § 402(2) (b).

216 E.g., Cat. Crv. Code \$1803.7; Conn. Gen. Stat. Rev. § 42-84(a) (1962); Dec. Code ANn. tit. 6, $\$ 4309$ (Supp. 1964); ItI. ANN. StaT. ch. 1211/2, \$226 (Smith-Hurd 1960); MD. ANN. CoDE art. 83, \$128(b) (1957); MAss. GeN. Laws AnN. ch. 255, § 13 (1956); N.J. STAT. ANN. § 17:16C-23 (1963); N.Y. PERS. Pror. LAW § 405; OHIo Rev. CODE ANN. \$1317.02 (Page 1962).

217 Exception is made for identifying numbers or marks and sometimes the due date of the first installment. E.g., ConN. GEN. STAT. Rev. \$ 42-84(a) (1962); ILL. AnN. STAT. ch. 1211/2, \$229 (Smith-Hurd 1960); MD. ANn. Code art. 83, \$130(a) (1957); N.J. Stat. ANN. \$17:16C-22 (1963); N.Y. Pers. Prop. Law \& 402 (4); Pa. S. 323, Sess. of 1965, §11(d) ; Note, 58 Colum. L. Rev. 854, 867 (1958).

218 These provisions are the most uniform of the retail installment sales acts. Id. at 869 ; e.g., CAL. CIV. CodE \$ 1803.3; CONN. GEN. STAT. REv. \$ 42-84(b) (1962); Del. Code AnN. tit. 6, § 4305 (Supp. 1964); Ill. ANN. Stat. ch. 12112, \& 225 (SmithHurd 1960); MD. ANN. Code art 83, \$129 (1957); MAss. GEN. LAws ANN. ch. 255, $\S 12$ (1956); N.J. Stat. ANN. \$17:16C-27 (1963); N.Y. Pers. Prop. Law $\$ 402$ (3) (b) ; Ohio Rev. Code Ann. \$1317.04 (Page 1962) ; Pa. S. 323, Sess. of 1965, $\$ 11(\mathrm{c})(2)$.

210 E.g., CaL. Crv. Code $\$ 1801.1$; Dex. Code ANN. tit. 6, § 4302 (Supp. 1964); IrL. ANn. Stat. ch. 1211/2, \&244 (Smith-Hurd 1960); MD. ANN. Code art. 83, $\S 148$ (1957); Pa. S. 323, Sess. of $1965, \S 24$. For a discussion of disclosure provisions see Hogan, $A$ Survey of State Retail Instalment Sales Legislation, 44 CoRNELI L.Q. 38, 44-47 (1958); Note, 58 ColuM. L. Rev. 854, 866-69 (1958).

220 Curran, Trends in Consumer Credit Legislation 270-77 (chart 13) (1965). 221 Donolow Committee Hearings, May 10, 1962, at 19-20 (statement of David Stahl, Attorney General of Pennsylvania). 
Unless these charges are regulated in all states, an incongruous situation will exist, since the rate charged the prospective purchaser in an independent loan transaction is controlled, while the identical charges made by the finance company as holder of a retail installment contract go unregulated. ${ }^{222}$

The regulation of finance charges required to prevent exhorbitant costs includes: restrictions on the maximum percentage rate and charges for late payment and prepayment; limitations on the "balloon note" technique calling for relatively small regular payments and a final large payment; close supervision of insurance charges; restrictions on "add-on" and acceleration provisions; and sections providing protections upon default. ${ }^{223}$

\section{Attorneys' Fees}

While a state agency may apply administrative sanctions against a retail installment seller and a district attorney may bring a criminal action, the consumer may still have to initiate a civil suit to effect restitution. ${ }^{224}$ California has enacted a provision in its retail sales act awarding reasonable attorneys' fees to the prevailing party in a private action regardless of whether initiated by buyer, seller or holder. ${ }^{225}$ A number of attorneys interviewed support such a statute on the grounds that it tends to alleviate the financial burden of initiating a private action which must be surmounted by any consumer wishing to assert a violation of the act.

\section{Conclusion}

Retail sales acts alone will not put an end to consumer fraud, but they do provide a useful tool not only to curb the unscrupulous businessman but also to set standards for all who deal in consumer credit. The businessman's claim that governmental regulation will serve to injure the legitimate concern has been answered by Barnett Levy, Assistant Attorney General in Charge of the Bureau of Consumer Frauds and Protection in New York. Mr. Levy has said that even if legitimate businesses incur additional expense and difficulty as a result of consumer protection legislation, the cost is a necessary one if the process saves millions of dollars for thousands of innocent consumers.

\section{B. Enforcement of Consumer Legislation}

\section{Use of Criminal Statutes}

Although the district attorney has the responsibility of enforcing state criminal laws, Tom could not obtain aid from this source. ${ }^{226}$ One reason

222 See cases cited note 116 supra; Koch, Time Sales Contracts and Other Pitfalls of Installment Lending, 28 TExAS B.J. 181 (1965).

223 See full discussion in Hogan, supra note 219 , at $47-65$; Note, 58 CoroM. L. REv. 854, 869-82 (1958).

224 In many instances, initiation of an investigation by an enforcement agency leads to the consumer's obtaining restitution without court action. See notes 273, 308, 387 infra and accompanying text.

225 CAL. CIV. CODE \& 1811.1.

226 See note 47 supra and accompanying text. 
for this lack of protection is the difficulty in obtaining convictions against fraudulent operators. To a great extent this is due to the restrictive interpretation which most courts give to false pretense statutes. ${ }^{227}$ It is widely held that to constitute a false pretense there must be an "assertion of an existing fact, not a promise to perform some act in the future." 228 This is true even if "the promisor never intended to perform." 229

An example of this important distinction can be found in the Pennsylvania case of Commonwealth v. Becker. ${ }^{230}$ There two counts of the indictment alleged that the defendant had promised each of his victims a new roof and had failed to make any attempt to perform. Conviction on one count was reversed because the defendant was paid before he commenced work and therefore "the money was not obtained under the false pretense . . . that a new roof had been installed." 231 The conviction on the second count was affirmed on the ground that the defendant was paid after representing that the new roof had already been installed, ${ }^{232}$ and this representation was sufficient to constitute the required false pretense.

This differentiation appears to be based chiefly upon the fear that if prosecution were permitted for false promises, "the way would be open for every victim of a bad bargain to resort to criminal proceedings to even the score with a judgment proof adversary." 233 In addition it is felt that there would be a real risk of prosecuting someone guilty of nothing more than an inability or refusal to pay his debts. ${ }^{234}$ These fears have been attacked by Chief Justice Traynor of the California Supreme Court in People v. Ashley: ${ }^{235}$

Whether the pretense is a false promise or a misrepresentation of fact, the defendant's intent must be proved in both instances by something more than mere proof of nonperformance or actual falsity . . . and the defendant is entitled to have the jury instructed to that effect. ${ }^{238}$

Although Joseph Stone, Chief of the Complaints Bureau of New York City's District Attorney's Office, believes that permitting false promises to be made criminal would flood his division with simple "breach of contract" cases, a few states have rejected the distinction between false promises

227 For a thorough discussion of the problem see Pearce, Theft by False Promises, 101 U. PA. L. REv. 967 (1953).

228 E.g., Commonwealth v. Moore, $99 \mathrm{~Pa} .570,574$ (1882). (1962).

229 Commonwealth v. Kelinson, 199 Pa. Super. 135, 143, 184 A.2d 374, 378

230151 Pa. Super. 169, 30 A.2d 195 (1943).

231 Id. at $172,30 \mathrm{~A} .2 \mathrm{~d}$ at 197.

232 Id. at $173,30 \mathrm{~A} .2 \mathrm{~d}$ at 197.

233 Chaplin v. United States, 157 F.2d 697, 699 (D.C. Cir. 1946).

234 Ibid.

23542 Cal. 2d 246, 267 P.2d 271, cert. denied, 348 U.S. 900 (1954).

236 Id. at 264,267 P.2d at 282. 
and false pretenses by judicial decision ${ }^{237}$ or statute. ${ }^{238}$ California is the only state whose courts have held that false pretenses include all promises made with intent not to perform, ${ }^{239}$ while Massachusetts and Rhode Island reach the same result by holding that false statements of present intention constitute false representations of an existing fact and are therefore criminally actionable. ${ }^{240}$ Two other states have amended their criminal statutes to include false promises made with present intention not to perform. ${ }^{241}$ Other statutes which prohibit "fraudulent representation, pretense, token, or writing" have been held by some courts to encompass promises as to "future facts, events and transactions." 242 Analysis of the litigation in states that have rejected the distinction leads to the conclusion that there is "not a shred of evidence" to substantiate fears that broadening the definition of false pretenses would hinder legitimate business operations. ${ }^{243}$

In addition to false pretense statutes, district attorneys can prosecute under a great number of narrowly drawn statutes which specifically prohibit a vast number of objectionable practices. ${ }^{244}$ In the area of fraudulent advertising, for example, the variety of statutes is almost unlimited. ${ }^{245}$

Yet, even when a law enforcement official believes that a particular scheme has been made actionable by statute, he often does not prosecute because of a widely held belief that, except in the most egregious circumstances, fraudulent operators should not be treated like criminals. Lawyers, business leaders and prosecutors have stated that "judges, juries and district attorneys do not like to put businessmen in jail." One district attorney, when asked by the attorney general to prosecute an alleged fraudulent

237 See People v. Ashley, 42 Cal. 2d 246, 267 P.2d 271, cert. denied, 348 U.S. 900 (1954); People v. Cohn, 358 Ill. 326, 193 N.E. 150 (1934); Commonwealth v. Green, 326 Mass. 344, 94 N.E.2d 260 (1950); State v. Singleton, 85 Ohio App. 245, 87 N.E.2d 358 (Ct. App. 1949) ; State v. McMahon, 49 R.I. 107, 140 Atl. 359 (1928).

238 Whoever (1) by false pretense or pretenses, or by a promissory representation as to some future action to be taken by the person making the representation where made with the present intent that such future action would not be performed or carried out ...

Neb. Rev. Stat. § 28-1207 (1964).

Any person who, knowingly or designedly, with intent to cheat or defraud any other person, obtains any . . . thing of value by means of false promises, statements, representations, tokens, writings or pretenses ....

N.J. Stat. AnN. §2A:111-1 (1953).

239 People v. Ashley, 42 Cal. 2d 246, 265, 267 P.2d 271, 283, cert. denied, 348 U.S. 900 (1954).

240 Commonwealth v. Green, 326 Mass. 344, 348, 94 N.E.2d 260, 264 (1950);

State v. McMahon, 49 R.I. 107, 108, 140 Ati. 359, 360 (1928).

241 See note 238 supra.

242 State v. Singleton, 85 Ohio App. 245, 261, 87 N.E.2d 358, 367 (Ct. App. 1949). 243 Pearce, supra note 227, at 1007.

244 In Pennsylvania, for example, individual statutes prohibit the fraudulent marking of an item as gold, gold fineness, silver, coin silver, or a mounting as sterling, or as coin. PA. Stat. ANn. tit. 18, $\$ \$ 4872-77$ (1963); see N.Y. Penal Law §§ 423-31.

245 Note, 56 Colum. L. Rev. 1018, 1097-1111 (1956). 
operator, retorted: "I can't even get a conviction when they stick a gun in somebody's back, how can I get one when they just talk him out of his money."

In addition, in the relatively few cases where convictions are obtained, many of the violators receive exceedingly mild treatment. The Philadelphia Bulletin was not particularly impressed with the "wrist slap" received by one racketeer:

C. Wilson Kile of Lansdowne should be a very happy man today.

He has been sentenced to one year in prison for making and selling fake automobile parts. He can serve a little jolt like this, as the racketeers say, "standing on his head." And keep a fortune which the N.Y. district attorney estimates at $\$ 300,000$, made by his crimes.

It is not reassuring to the public to know that he will be at liberty in a year, to resume the dangerous activities .... ${ }^{246}$

\section{Injunctive Protection}

In order to overcome the difficulty of obtaining meaningful criminal sanctions, it has been suggested that "states adopt legislation aimed at protecting the consumer by . . . use of an injunction." 247 Recently, a few states have adopted such legislation permitting a law enforcement official to petition the court for an injunction prohibiting any "deception, fraud, false pretense, false promise, [or] misrepresentation . . . in connection with the sale or advertisement of any merchandise." 248 The prerequisites for criminal prosecution, namely, knowledge of the falsity of the statements made and intent to defraud, are not required in these injunction statutes. ${ }^{249}$ No one need be defrauded and indeed the injunction can be granted when a likelilood exists that a person "is about to engage in" a practice made illegal by the act. ${ }^{250}$ Furthermore, while most legislatures and courts consistently assert that criminal false pretense statutes require the misrepresentation of a past or presently existing fact, ${ }^{251}$ an injunction statute is not criminal in nature and can more easily include "a false promise."

246 Philadelphia Evening Bulletin, August 25, 1955, p. 12, col. 1.

247 Memorandum From the Chief of the Ohio Consumer Frauds and Crimes Section of the Attorney General's Office 7, on file in Biddle Law Library, University of Pennsylvania [hereinafter cited as Ohio Memorandum].

248 IlL. AnN. Stat. ch. 1211/2, \$ 262 (Smith-Hurd Supp. 1964) ; N.J. STat. ANN. $\S 56: 8-2$ (1964); see Minn. Stat. Ann. \&325.79 (Supp. 1964); N.D. Cent. Code $\$$ 51-15-02 (Supp. 1965).

249 "[C]riminal action is limited by the requirement of proof of a requisite intent to defraud. Because criminal law and the law of fraud in particular finds its roots in common law, the traditional stringent requirements of definite proof of the elements of the crime impedes successful prosecution of many cases." Ohio Memorandum 7. 250 Irl. Ann. Stat. ch. 1211/2, § 267 (Smith-Hurd Supp. 1964) ; N.J. STAt. AnN. $\S 56: 8-8$ (1964); see MinN. Stat. AnN. \$325.80 (Supp. 1964); N.D. CENT. Code $\S 51-15-07$ (Supp. 1965).

251 See notes 227-232 supro and accompanying text. 
Another important consumer benefit provided by these statutes, is the power they give the law enforcement official to petition the court "to restore to any person in interest any moneys or property, real or personal which may have been acquired by means of any practices declared to be unlawful." 252 Reparation thus can be obtained without the payment of attorney's fees. ${ }^{253}$ In addition, an injunction is directed against halting a company's particular practice, while criminal prosecution leads only to the incarceration of a particular individual and the activity can be continued by other members of his business. ${ }^{254}$

The mere threat of an injunction should in many cases halt the offending activities without the need for its issuance to formalize the effectiveness of this threat. New York has adopted a procedure whereby the attorney general promises not to seek an injunction against any company filing "an assurance of discontinuance of any act or practice" considered illegal under the act. ${ }^{255}$ It also may be stipulated that the alleged violator make a "voluntary payment" of the state's "cost of investigation" in an amount up to 2,000 dollars. ${ }^{256}$ No action by any court is provided for in the statute outlining this process. Noncompliance by the company with its "assurance," constitutes prima facie evidence in any civil action or proceeding instituted by the attorney general. ${ }^{257}$

Injunction statutes of this type are of recent vintage and thus the many questions which will arise in their administration have not as yet been fully resolved through litigation. Hopefully, legislators will realize the potential benefits of this type statute in reducing fraud, and prosecution under the resulting injunction statutes will effectively resolve any problems presented.

\section{Shift of Responsibility to State Officials}

Another attempt to protect more effectively the consumer has led some states to shift the primary responsibility for enforcing consumer legislation

252 Il. . Ann. Stat. ch. 1211/2, \$267 (Smith-Hurd Supp. 1964) ; N.J. Stat. Ann. § 56:8-8 (1964) ; N.D. CENT. CODE \& 51-15-06 (Supp. 1965).

253 "Even if investigation produces enough evidence to bring a case to court, and the district attorney is able to get a conviction, it remains for the complainant to bring action to recover whatever losses he may have suffered." N.Y. Herald Tribune, March 7, 1965, p. 4 (Magazine).

254 The District Attorney of Philadelphia was recently faced with a rash of cases involving false and misleading practices in the sale and advertisement of carpeting. Criminal prosecution of the offenders was rejected because it was felt that this would only halt individual salesmen. Frauds Division Files; see note 261 infra.

Instead an injunction was sought, and defendants in a consent decree agreed to halt certain objectionable activities. Commonwealth ex rel. Crumlish v. Carpetland \& Carpetville, Inc., Case No. 4042, Phila. C.P. No. 8, July 29, 1964.

255 N.Y. Exec. LAW $\S 63(15)$. See also WASH. REv. Code ANn. $\$ 19: 86: 100$ (Supp. 1964).

258 N.Y. EXEC. LAw \$63(15). According to the 1964 Annual Report of the New York State Bureau of Consumer Frauds \& Protection, on file in Biddle Law Library, University of Pennsylvania [hereinafter cited as N.Y. Report], a total of $\$ 22,812.00$ was collected by the state treasury under this statute.

257 N.Y. EXEC. LAW § 63(15). 
from local district attorneys to state officials or agencies.258 The main reason for this change is that local officials have been overburdened with the problems incident to protecting the public from physical harm ${ }^{259}$ and have not been able to enforce consumer legislation. ${ }^{260}$ For example, a study of prosecutions under false advertising statutes "showed clearly that most jurisdictions have never used the statutes at all, and that only a few have initiated more than a handful of prosecutions." 261 Some local law enforcement officials do not even consider enforcement of advertising laws their responsibility, adopting an attitude similar to that expressed by an assistant district attorney of a large Pennsylvania county: "Harrisburg passed these laws; they should certainly enforce them." Yet the authority of Pennsylvania state officials to enter into or initiate prosecution of even the most flagrant violators is extremely limited.262

Shifting the burden of consumer protection to statewide agencies appears to have led to more effective enforcement in states which have adopted this procedure. A statewide organization can more readily assess the most effective means of halting widespread fraudulent practices, and its extensive authority will give it the power to do so. These agencies also have larger staffs than most municipalities and therefore can appoint one man or even a group of men to deal exclusively with consumer problems.

Reliance on state authority, however, need not entail the complete removal of the district attorneys' powers to enforce consumer statutes. Local operations might escape surveillance by a statewide office and individual district attorneys may well be interested in solving their own problems. A

$258 \mathrm{~A}$ recent study of consumer protection activities concludes that "a trend is rapidly developing to expand the function of the State Attorney General to deal directly with consumer fraud protection ...." National Better Business Bureau, The Growth of State Consumer Frauds Bureaus, June 1965, p. 4 [hereinafter cited as Fraud Bureaus]. (1956).

259 Interview With District Attorney; cf. Note, 56 CoLum. L. REv. 1018, 1064

260 Three assistant district attorneys interviewed in one Pennsylvania county asserted that they could recall only one instance when a fraud case had been prosecuted in their county.

261 See Note, 56 ColuMr. L. Rev. 1018, 1063 (1956). A study of the cases under the Pennsylvania advertising statute, PA. STAT. ANN. tit. 18, §4857 (1963), disclosed no reported convictions. Commonwealth v. Masters of Lancaster, Inc., $199 \mathrm{~Pa}$. Super. 36, 40, 184 A. 2d 347, 350 (1962) asserts that there exists only one other case which discusses the construction of the statute. The second case is contained in an old district court report, Commonwealth ex rel. Cunningham v. Dean, $30 \mathrm{~Pa}$. Dist. 563 (Ct. Quarter Sess. Philadelphia County, 1921).

262 See PA. Stat. ANN. tit. 71, $\$ 817$ (1962) (attorney general can intervene only when requested to do so in writing by president judge of district having jurisdiction). A Pennsylvania deputy attorney general stated that this permission was very difficult to obtain and therefore was rarely requested.

The better business bureau survey of consumer fraud bureaus stated that "some Attorneys General reported that they have no authority, responsibility or facilities to investigate or prosecute those who perpetrate consumer frauds." Fraud Bureaus. See also statement by the Attorney General of Ohio that "the Attorney General does not have the authority, nor does he think it proper, for his office to enter into the fields of investigation and prosecution." Ohio Consumer Frauds and Crimes Bull. 2-118-64 (Feb. 1964) [hereinafter cited as Ohio Bulletin]. 
grant of concurrent jurisdiction should provide both with the necessary powers. $^{283}$

\section{Consumer Fraud Bureaus}

A growing number of states have entrusted enforcement of consumer laws to special bureaus organized to deal with all aspects of the problem. The first such agency, the New York State Bureau of Consumer Frauds and Protection, was established in 1959. ${ }^{264}$ Seventeen other states now have some type of organization, ${ }^{265}$ although each organization differs widely in its statutory authority, scope of operation and even as to the governmental department under which it functions. The overall success of these bureaus depends not only upon their ability to enforce legislation but also upon their development of comprehensive programs dealing with all facets of consumer protection.

\section{Functions}

The chief of the New York Frauds Bureau, for example, estimates that more than ninety percent of the work of his organization is devoted to mediating buyer and seller disagreements. ${ }^{268}$ During 1964 more than eleven thousand consumers visited the frauds bureau office to register complaints, ${ }^{267}$ and thousands of persons, many from other states and foreign countries, wrote that they were defrauded by New York businessmen. ${ }^{268}$ Each grievance, no matter how small, is processed by one of the fifteen staff members. ${ }^{269}$ While a few are deemed unfounded, ${ }^{270}$ most of the

263 See, e.g., Minn. Stat. ANN. $\$ 325.80$ (Supp. 1964) (injunction power given to Commissioner of Business Development and to county district attorneys).

264 Warne, "Consumer Protective Movements on the State and Local Levels1964," at 19, on file in Biddle Law Library, University of Pennsylvania [hereinafter cited as Warne]; Fraud Bureaus 1. Two years earlier, the attorney general had named two assistants to handle complaints. See ibid.; 1957 N.Y. Atr'y GENERAL ANNUAL REP. 29. The bureau was then formed because of the increasing number of complaints.

265 The Better Business Bureau reports that there are 15 bureaus, Fraud $\mathrm{Bu}$ reaus 1. A Reader's Digest report adds two additional states, Eisenberg, You Can Get Your Money Back, Reader's Digest, Feb. 1964, pp. 131, 135. Still another state is added by. Warne 27. The states included are: Alaska, California, Connecticut, Hawaii. Illinois, Kansas, Massachusetts, Maine, Michigan, Minnesota, Missouri, North Dakota, New Jersey, New Mexico, New York, Ohio, Washington, and Wisconsin.

266 Information about the New York bureau was obtained in an interview with Chief Barnett Levy. The bureau describes its four areas of activity as mediation, education, legislation, and litigation. N.Y. Report 1.

267 Ibid.

268 The Bureau received over 25,000 pieces of mail in 1964 and made or received more than 60,000 telephone calls. Ibid. Its most publicized international complaint was registered by Cuban residents who had been defrauded by a New York travel agency. The Bureau prosecuted the agency officials and also sent several representatives to Mexico City to aid prosecutions that had been instituted there. N.Y. Report 4.

269 Eisenberg, supra note 265, at 135.

270 "When we feel that a consumer's claim is unjustified, we tell him so. We won't knuckle under to a firm, but neither will we browbeat it." Id. at 134 (statement by New York Bureau Chief). 
others are settled by a phone call to the company to iron out misunderstandings. When court action is deemed necessary to halt any practice which the company refuses to discontinue, ${ }^{271}$ the proceeding is instituted by the attorney general on behalf of all interested parties and the consumer pays no attorneys' fees. ${ }^{272}$ More than a million dollars has been returned to defrauded consumers as a result of the bureau's informal mediation process and court action. . $^{273}$

The California Consumer Counsel, on the other hand, functions primarily as an advisor to the Governor, recommending consumer legislation and lobbying for its passage. ${ }^{274}$ Pursuant to the latter function, agency representatives appear at administrative hearings, and before legislative study committees, and other governmental groups that deal with consumer problems. ${ }^{275}$

Consumer fraud bureaus also serve a useful function by aiding industry self-regulation attempts. ${ }^{276}$ The New York bureau, for example, holds conferences with automobile industry representatives to discuss programs aimed at the elimination of misleading advertising and selling practices. ${ }^{277}$ Plans are also being instituted for the joint drafting of a code of ethics by the bureau and the hearing aid industry-"the first Industry-Government code established in the country." 278

Other consumer protection groups emphasize their function of serving as "a coordinating or clearing agency to assist local and state governmental agencies [in preventing] . . fraudulent practices in advertising, sales and other fields." 279 The need for a statewide agency to fulfill this role was outlined by the chief of the Ohio Attorney General's Consumer Frauds and Crimes Section:

Often time is of the essence in stopping consumer frauds. Just as fast as they talk, these perpetrators of consumer frauds move off into greener pastures. If the need to report to a central clearing house is impressed deeply upon local law enforcement officers, this office could relay the information rapidly and have all local law

271 See notes 255-257 supra and accompanying text.

27?2 See N.Y. Pers. Prop. LAW §63(12).

273 N.Y. Report 11. In one order, a New York supreme court dissolved a corporation which had defrauded thousands of homeowners through a deceptive referral plan and provided for a $\$ 25,000$ escrow fund for complaint adjustments. Id. at 8.

274 See CaL. Gov't Code $\$ \$ 12050-057$. See generally 23 LEgAL AID Brisf Case 267-69 (1965).

275 Cal. Gov't Code $\$ 12055(a)$; see Sone Consumer Gains in Calffornia 2-10 (1964).

276 In this regard see discussion of better business bureau activity, supra note 70 and accompanying text.

277 N.Y. Report 6.

$278 I d$. at 2.

279 Ietter From Col. George Mingle, Chief, Consumer Frauds and Crimes Section, Office of the Ohio Attorney General to the University of Pennsylvania Laze Reviez, July 20,1965, on file in Biddle Law Library, University of Pennsylvania. 
enforcement agencies on the lookout for specific practitioners of the art of fraud. 280

This consumer bureau has instituted a bulletin service connecting more than twelve hundred different Ohio agencies including prosecuting attorneys, sheriffs, police offices and better business bureaus. These bulletins deal with more than forty topics covering activities of a possibly illegal nature 281 and include information concerning the activities of groups of fraudulent operators ${ }^{282}$ and the results of investigations by the attorney general's office ${ }^{283}$ and the functions of various state ${ }^{284}$ and federal agencies. 285

Additional methods of coordinating statewide fraud prevention programs have also been devised. Michigan's consumer fraud bureau, for example, advises private attorneys and county district attorneys "concerning legal theories and approaches that may be used in dealing with business firms which have improper business practices." 280 California has attacked this problem on two fronts. First, the Governor's Consumer Counsel has instituted a training program for local law enforcement officials which emphasizes specialized methods of detection and prosecution of defrauders. ${ }^{287}$ At the same time the consumer fraud unit of the attorney general's office undertakes multi-county fraud investigations with local law enforcement officials. ${ }^{288}$

To be even more effective bureaus should also supplement their intrastate coordination plans by initiating programs of cooperation with law enforcement officials and protection agencies in other states to form a national fraud network. President Johnson's Special Assistant for Consumer Affairs has announced that plans have been made "to work closely

280 Ohio Memorandum 5.

281 Letter From Col. George Mingle, Chief Consumer Frauds and Crimes Section, Office of the Ohio Attorney General to the University of Pennsylvania Law Revieze, July 20, 1965, on file in Biddle Law Library, University of Pennsylvania. E.g., Ohio Bulletin 6-144-65 (June, 1965) (bait advertising) ; 8-104-63 (Aug., 1963) (debt pooling). California Consumer Counsel also publishes a bulletin for law enforcement officials, containing reports of action taken against fraudulent operators by various governmental agencies. CALIFORNIA CONSUMER CounsEL REP. 18 (1962) [hereinafter cited as CALIFORNIA REP.].

282 Ohio Bulletin 5-123-64 (May, 1964) (description of fraudulent operation out of Pittsburgh).

283 Ohio Bulletin 8-103-63 (Aug., 1963) (used car sales); 10-110-63 (Oct., 1963) (loan solicitations by mail).

284 Ohio Bulletin 3-140-65 (March, 1965) (state securities division).

285 Ohio Bulletin 2-138-65 (Feb., 1965) (Federal Trade Commission); 1-136-65 (Jan., 1965) (Post Office).

${ }^{286}$ Letter From Maurice E. Funt, Field Representative, Consumer Protection, Antitrust and Public Service Division, State of Michigan, to the University of Pemsylvania Law Review, June 28, 1965, on file in Biddle Law Library, University of Pennsylvania.

287 California Rep. 18.

288 Frauds Bureau 3. 
with the National Association of Attorneys' General to recommend ways to coordinate the consumer fraud activities in the states." 289

Consumer councils should also assist in informing the public of the "pitfalls they face in today's market place and in their homes." 290 Mass dissemination of leaflets, ${ }^{291}$ consumer conferences, speeches before interested groups and over mass media, and movies outlining consumer problems have all been integrated into successful consumer education programs. ${ }^{202}$

\section{Formation}

Only five of the consumer fraud bureaus established to date have been authorized by statute. ${ }^{293}$ The others have been organized by the attorney general simply designating assistants who are to assume consumer protection functions. ${ }^{204}$ In describing the formation of his office, Barnett Levy, Chief of the New York Bureau, remarked that "we might still not be started if we had to wait for an enabling statute." He stated that New York's Attorney General, Louis Lefkowitz, felt that one of his duties was to protect consumers and directed that part of his budget be set aside each year to perform this function. Once a bureau is formed, Mr. Levy explained, it becomes easier to secure the passage of desired legislation ${ }^{295}$ and to obtain the funds necessary to expand facilities. A Pennsylvania state senator stated that if a bureau were organized by the attorney general, it would be difficult to vote against appropriations which might halt or curtail its work because of the likelihood of voter disapproval. Statutes authorizing the formation of consumer councils, however, may serve the function of clearly defining the purposes for which a bureau is created, expanding in some cases the scope of activities beyond that which the attorney general would otherwise perform. States have passed statutes authorizing the governor to appoint an individual ${ }^{296}$ or a committee ${ }^{297}$ to advise him, or expanding the consumer protection duties of an existing agency. ${ }^{298}$

The problems that exist in a state without a consumer council were vividly indicated recently in Pennsylvania. After publication of a magazine

280 Letter From Esther Peterson to the University of Pemnsylvania Law Review, July 7, 1965, on file in Biddle Law Library, University of Pennsylvania.

200 N.Y. Report 7.

201 The New York Bureau, for example, distributes a pamphlet, "Your A B C's of Careful Buying," which it prints in both English and Spanish. Ibid.

292 See N.Y. Bureau 7; CAIIFORNIA REP. 17.

293 Cal. Gov't Code $\$ \$ 12050-57$; Conn. Gen. Stat. Ann. $\$ 19-170$ a (1958); Hawaii Laws 1964, Act 50, p. 65 (directive on use of appropriations to attorney general's office); Mass. Gen. Laws AnN. ch. 6, \$115 (1963); Minn. Stat. AnN. $\$ 362.07-.241$ (1957) (consumer protection functions given to commissioner of business development).

204 See Warne iii-iv.

295 See, e.g., N.Y. Exec. Laws §63(15); N.Y. Gen. Bus. LAw § 350.

296 E.g., CAL. Gov't CODE $\$ 12050$.

207 The Massachusetts council consists of eight members, one of which must be a representative of the AFL-CIO and no more than five of which may represent one political party. Mass. Gen. Laws ANn. ch, 6, §115 (1963).

298 In Minnesota the function is handled by the Commissioner of Business Development. Minn. Stat. AnN. \$ 362.07-.241 (1957). 
article telling citizens in states where no fraud bureau existed to "register your complaint with your attorney general," 299 "literally hundreds of complaints poured into [the attorney general's office] . . . . We just had to tell the people that we weren't set up to handle complaints and they'd have to see either a private attorney or obtain a criminal warrant from a magistrate." 300

Even more significant is that there is little chance of improvement in the Pennsylvania situation in the near future. Those who claim that Pennsylvania's problems will be solved by one of the four bills introduced into the legislature this session ${ }^{301}$ to establish a consumer council should bear in mind the deaths of the four previous bills introduced in earlier sessions. ${ }^{302}$ Even though the chances of passage for such a bill have been assessed as "dismal," 303 the attorney general's office refuses to take the initiative in helping the consumer battle fraudulent operators.

\section{Local Bureaus}

In states that do not as yet have consumer councils, county district attorneys' offices may help fill the void that exists in consumer protection. In 1961 the Philadelphia District Attorney's office created a frauds division in its complaint department. ${ }^{304}$ Ten county detectives are assigned to listen to fraud complaints on a full time basis. In cases clearly within the criminal statutes, where the scheme has caused great harm to the public or a particular individual, even a single complaint may trigger an investigation by the division and a report to the legal staff for prosecution. ${ }^{305}$

Even when the complaint is civil in nature, the detective will try to arrange a settlement despite the fact that his only official duty is to "advise the complainant to seek the services of a qualified attorney." 308 He will always make a phone call or write a letter in an attempt to resolve any misunderstanding no matter how small the amount involved. ${ }^{307}$ The mere

299 Eisenberg, supra note 265, at 135.

300 Interview With Pennsylvania Deputy Attorney General. Complaints were also made in other states, causing the Attorney General of Ohio, for example, to assert that it led to "considerable misunderstandings in our state." Ohio Bulletin 2-118-64 (Feb., 1964).

301 Pa. S. No. 391, Sess. of 1965; Pa. H.R. Nos. 181, 455, 734 Sess. of 1965.

302 Pa H.R. No. 1417, Sess. of 1963 ; Pa. S. No. 655, Sess. of 1961; Pa. H.R. Nos. 2088, 2347, Sess. of 1959.

303 Interview With Counsel To Pennsylvania State Investigating Committee.

304 Information about this program was obtained in interviews with James C. Crumlish, Jr., District Attorney, Francis J. Lederer, Chief of County Detectives, and Joseph McCarrie, Sergeant in Charge of the Frauds Division. The authors of this comment were given access to the confidential files of the frauds division and wish to express their appreciation to Assistant District Attorney Anthony J. Smith, Chief of the Complaints Division.

305 See Philadelphia Inquirer, Aug. 26, 1965, p. 33, col. 1 (two men arrested on charges of cheating an 87 year old, partially blind man out of more than $\$ 10,000$ in a home improvement scheme).

306 The District Attorney's Office [Philadelphia], Public News Bull. No. 2.

307 The frauds division's smallest case involved efforts resulting in a refund of twenty cents to a complainant who had received a previous day's newspaper when he deposited money in a coinbox. Frauds Division Files. 
fact that it is the district attorney's office which is conducting the negotiations serves to induce businessmen to adjust consumer complaints. ${ }^{308}$ If after a number of complaints the sellers remain adamant in their refusal to negotiate, the detective will "tell the companies that if they don't cooperate, we'll put a red line under their names and will prosecute if they cause any more trouble." 309 District Attorney James C. Crumlish, Jr., reported to a state senate committee that:

[T] hese people who are in business in these borderline activities are so sensitive to the possibilities of stepping over the line or being caught over the line at a future date that they are usually amenable to our suggestion that some negotiation be entered into and worked out, not based upon actual criminal violation but the authority of the office to step in when one subsequently develops. ${ }^{310}$

In cases where negotiations fail and the detective believes that prosecution is not warranted, he will record the complaint and advise the consumer to seek the services of a private attorney, the legal aid society, or a magistrate. ${ }^{311}$ However, if a large number of charges are leveled against one company and attempts at negotiations have failed, a complete investigation will be conducted to ascertain if grounds for criminal prosecution exist.

Most district attorneys unfortunately do not offer these services. As an attorney in one Pennsylvania county wrote to the Philadelphia frauds division: "As you are probably aware, our District Attorney's office out here is in no real position to handle any of these fraud complaints and generally does not even keep any records in regard to the complaints primarily because they are not equipped to handle them." 312 Even a large city like Pittsburgh lacks any formal program to aid defrauded consumers since, as stated by an assistant district attorney, "our work force is too small and we are swamped with burglaries, murders, and habeas corpus applications." Although some effort is made to arrange settlements, the fear of a rash of complaints leads to the policy that "we don't want to publicize what we do."

In addition to helping the consumer settle his disputes and sending him to the agencies that can best serve him, the presence of a frauds division serves to bring more cases of criminal fraud to the attention of the district

308 Although no money ever passes through the hands of members of the frauds division staff, it is estimated that more than a $\$ 100,000$ a year is recovered by consumers as a result of the division's intervention.

309 When the frauds division had received twenty-two complaints about a particular freezer company, the company was informed "that if there were any recurrences of complaints . . then our office would have to take a very serious view toward the situation and take action against the company." Frauds Division Files.

310 Donolow Committee Hearings, May 10, 1962, at 113.

311 During 1964, 1,150 complaints were received by the Frauds Division. Of these 524 were adjusted and closed, 147 were referred to others, and 479 were considered unfounded. Figures released by Philadelphia District Attorney's Office.

312 Frauds Division Files. 
attorney's office. By putting unethical businessmen on notice that their activities are under surveillance, the frauds division also discourages many fraudulent schemes before they begin.

\section{The Minor Judiciary and the Small Claims Court}

Tom's "arrest" for failure to pay the finance company, ${ }^{313}$ clearly a violation of "a fundamental principle of law that a criminal prosecution may not be used to collect a civil debt," 314 provides an extreme example of the flagrant misuse of legal process by the minor judiciary.

Tactics such as those employed against Tom have been used by collection agencies, constables and local magistrates in Philadelphia.315 Other practices also aimed at harassing alleged debtors have included vicious dunning letters, abusive telephone calls and in one reported case a debtor was even threatened with a revolver to insure payment. ${ }^{316}$ Even though statutes provide the consumer with a forum where he can present a fraud claim against a company or offer the defense of misrepresentation against a claim for money owed, he may still be denied a fair disposition of his case.

If a debtor is accorded a hearing in magistrate's court, he may be denied the fundamental right of having an impartial judge decide his case. Many lawyers inform debtors that, because of the connection between the constable and the magistrate, "any attempt to resist collection is futile . . . even though the debtor has a valid defense." 317 Indeed the "plaintiff won more than ninety-nine percent of the cases heard in those courts." 318

Some Philadelphia magistrates, moreover, have repeatedly violated the Pennsylvania Constitution ${ }^{319}$ by adjudicating cases which involve over 100 dollars and therefore are outside their jurisdiction..$^{320}$ In addition, magistrates have refused to follow court cases holding that debt in excess of 100 dollars cannot be waived or remitted by the plaintiff in order to give the magistrate jurisdiction. ${ }^{321}$

If Tom had paid for his carpeting and then sued in a magistrate's court for a refund, he most likely would have received a judgment in his favor, since virtually all plaintiffs succeed, ${ }^{322}$ but he would have been faced with a number of difficulties collecting it. Magistrates may refuse to fulfill their statutory duty of granting the writ of execution on the judgment, ${ }^{323}$ and both the constable, who attempts to collect the judgment, and the

313 See note 54 supra and accompanying text.

314 Magistrates Report 439; see PA. Stat. AnN. tit. 12, \$257 (1953).

315 For a thorough study of this process see "The Collection Mill," Magistrates REPORT 422-52.

$318 \mathrm{Id}$. at 27.

317 See ibid.

$318 \mathrm{Id}$. at 398.

319 PA. Const. art. V, § 12.

320 Magistrates Report 350-51.

321 Id. at 351-55.

322 See note 318 supra and accompanying text.

323 Magistrates Report 400-04. 
magistrate may charge rates in excess of the maximum set by statute..$^{324}$ Execution may not be successful, however, even if these difficulties are overcome, since the defendant is often an undercapitalized or fly by night corporation with no assets.

Thirty-four states have found "the old-fashioned method of allowing small causes to be determined by untrained justices of the peace . . . entirely unsatisfactory" 325 and have inaugurated a system of courts devoted to the settling of small claims. ${ }^{326}$ These courts are specially organized so as to provide "a simple, informal and inexpensive procedure for the prompt determination of such claims in accordance with the rules and principles of substantive law." ${ }^{327}$ Informal procedures adopted by many of these courts include increased conciliation attempts, service of process by mail, waiver of many of the technical rules of evidence, elimination of a jury, limited right of appeal, and increased control of the hearing by the judge, who is given discretion to determine whether witnesses should be called, and to set what he considers realistic terms for payment of a judgment. $^{328}$ The inexpensiveness of litigating in these courts ${ }^{329}$ has insured that "many well-founded claims are presented which would never have seen light of day because of the expense in bringing suit." ${ }^{330}$

Some small claims courts bar attorneys, ${ }^{331}$ literally accepting Roscoe Pound's view that "it is a denial of justice in small causes to drive litigants to employ lawyers. . . ." 332 The California District Court of Appeals in Prudential Ins. Co. v. Small Claims Court ${ }^{333}$ decided that such a bar was necessary to fulfill the courts' basic functions: "If one of the litigants in such a court could employ counsel it would of necessity mean that the poor untrained litigant who could not afford to pay such costs would be at a disadvantage." ${ }^{334}$ The court held the provision not to be a denial of due process on the ground that, if the plaintiff wished an attorney, he could bring his claim in other courts, and the defendant similarly could not

324 Id. at $416-18$.

325 Scott, Snall Causes and Poor Litigants, 9 A.B.A.J. 457 (1923).

326 See Institute of Judicial Administration, Smali Claims Courts in the UTited States 1 (1955, Supp. 1959) [hereinafter cited as Sarall Clatms Couris]. For a detailed analysis of these courts see id. at 1-18 (Supp. 1959); id. at 1-48 (1955). 327 N.Y. JudrCIARY LAW $\S 1802$.

328 Sarall Claims Courts 1-2.

329 California, for example, charges a fee of one dollar for filing of an affidavit and commencement of an action, one dollar for each copy mailed to a defendant, and one dollar for issuance of the writ of execution. CAL. CODE CIV. PROc. \$117(p). For a booklet informing the public of these minimal charges see CALIFoRNIA CoNsumer Counsei, How To Use the Small Claims Court.

830 SMall Clamis Courts 11.

831 Id. at 9.

332 Pound, The Administration of Justice in the Modern City, 26 HARv. L. Rev. 302, 318 (1913).

33376 Cal. App. 2d 379, 173 P.2d 38 (Dist. Ct. App. 1946).

334 Id. at 383,173 P.2d at $40-41$. 
complain as he had a right to appeal from the small claims court to the superior court, where he would be entitled to a trial de novo. ${ }^{\mathbf{3 3 5}}$

Permitting the attendance of attorneys in small claims courts tends to hinder the attempt to conduct a simple and informal trial. A District of Columbia court, for example, felt constrained to hold that it was improper for a judge in a small claims court to conduct direct examination of the plaintiff, to rule out some of plaintiff's testimony as irrelevant before allowing his attorney to examine him, and to intimate during the proceeding that the plaintiff would be unsuccessful. ${ }^{336}$ The statement in the court's opinion that "it was never intended that . . . there be any interference with [lawyer's] traditional functions" 337 is contrary to Dean Pound's view that wide latitude should be given to a judge who "represents both parties and the law . . . [in order that he can] get away from the involved and over-mechanical procedure which has become in so many jurisdictions a means afforded each party of hindering the other in his search for justice." 338

\section{Federal Governanent}

The federal government's direct concern for a full scale program of consumer protection is a very recent development. In March, 1962, President Kennedy became the first chief executive to send a special message on consumer interests to Congress. ${ }^{339}$ None of the earlier efforts by national officials to "bring the consumer point of view into the federal government" resulted in permanent representation. ${ }^{340}$ Reasons suggested to explain the "succession of "failures" include: an historical conception of "consumer advice" as only part of an emergency plan; the unpopularity of consumer advisors with organizations to which they are attached; and a failure to recognize that consumers need attention more specific than the general mandate given to governmental agencies to further the "public interest." 341

President Kennedy, in an attempt to ensure the consumer interest a continuous voice in the federal government, created the Consumer Advisory Council to suggest legislation and to advise the president. ${ }^{342}$

Initially, the Council was hampered by limited staff and funds. ${ }^{343}$ In its first year it concentrated on familiarizing itself with the existing programs and practices of the federal agencies in order to determine how these organizations could be better utilized. ${ }^{344}$ The Council's proposals for legis-

$335 \mathrm{Id}$. at 382, 173 P.2d at 40; accord, Foster v. Walus, 81 Idaho 452,347 P.2d 120 (1959).

336 Gaddis v. Hongell, 117 A.2d 230 (D.C. Munic. Ct. App. 1955).

337 Id. at 231.

338 Pound, sipra note 332, at 319.

339 Consumer Advisory Council ANN. Rep. 5 (1963) [hereinafter cited as CouncIl Report]. For the text of the message see 108 Cong. REc. 4167-4171 (1962). 340 COUNCIL REPORT 30.

341 Ibid.

342108 Cong. Rec. 4169 (1962).

343 COUNCIL REPORT 8.

344 Id. at 9. 
lative and procedural change were then channeled to appropriate members of the administration. ${ }^{345}$

A second directive from President Kennedy called for designation of special assistants in each of the twenty-two federal agencies whose activities bear significantly on consumer welfare. ${ }^{348}$ The assistants were to promote the consumer interest in all actions taken by these agencies. ${ }^{347}$ This program began with considerable publicity and included a general invitation to send complaints of consumer fraud to the White House. ${ }^{348}$ However, it has resulted that "small consumers . . . who have sought practical concrete advice on how to obtain satisfaction for their complaints in specific cases have been disappointed. Indeed, . . . there has been a reversal of policy and word has apparently gone out that attention to problems in such detail has not been found practicable." 349

President Johnson also sent a consumer message to Congress, ${ }^{350}$ in an attempt to implement the Consumer Advisory Council's recommendation for stronger and more effective representation at the presidential level. ${ }^{351}$ He appointed a new Special Assistant for Consumer Affairs and established the President's Committee on Consumer Interests which was to conduct a series of regional conferences, examine existing programs aimed at providing consumer information to families and expand consumer programs in the schools. 352

Both Presidents Kennedy and Johnson called for specific legislation, including proposals to strengthen present laws covering food, drugs, and cosmetics which "are inadequate to assure the necessary protection the consumer deserves." 353 Each chief executive also supported "truth in lending" 354 and "truth in packaging" ${ }^{555}$ bills, and praised agency work in the federal government's two most significant direct fraud prevention programs-the Post Office's mail fraud jurisdiction and the Federal Trade Commission's power to take action against false advertising. ${ }^{356}$

845 Ibid. For a summary of the Council's accomplishments, see id. at 9-10. 346108 Cong. Rec. 4169 (1962). For a list of the agencies see CouncIL REPORT 7.

347108 Cong. Rec. 4169 (1962).

348 Consumer Bull., Nov. 1964, p. 18.

349 Ibid.

350 110 Cong. REc. 1958-1960 (1964).

851 COUNCIL Report 30.

852 110 Cong. REc. 1960 (1964). The Committee consists of representatives of the federal agencies most concerned with consumer affairs and members of the Consumer Advisory Council with the Presidential Assistant as chairman. Id. at 1958. 353108 Cong. Rec. 4169 (1962); see 110 Cong. REC. 1959 (1964). 354 For present bills see S. 2275, H.R. 111, 89th Cong., 1st Sess. (1965).

355 For present bills see S. 985, H.R. 1664, 89th Cong., 1st Sess. (1965).

356 The statutes, passed originally in 1872 , were the earliest federal legislation concerned directly with consumer protection. CounCII REPORT 24. 


\section{A. The Post Office}

The two postal fraud statutes-the first providing criminal penalties for use of the mail to defraud, ${ }^{357}$ the second an administrative statute empowering the Postmaster General to stop incoming mail from reaching the fraudulent operator ${ }^{358}$ - constitute effective weapons for governmental protection of the consumer. ${ }^{359}$ Due to the postal authorities' effective use of these statutes "the smart guys have been forced to avoid carefully the use of the mails." 360

If the referral scheme which the salesman outlined to Tom ${ }^{361}$ had been described in a letter, a complaint that he had been defrauded could have been made at one of fifteen postal inspection headquarters. ${ }^{362}$ Despite official policy that "the Post Office Department has no authority to recover your money or property or take any action to adjust an unsatisfactory transaction," ${ }^{363}$ some inspectors will begin processing a consumer's complaint of mail fraud, ${ }^{364}$ even if solely a civil question is involved, ${ }^{365}$ by attempting to resolve any difficulty with a telephone call or letter to the offending seller. If the postal inspector, after detailed investigation, concludes that a criminal action should be instituted, his finding of "intent to defraud" is submitted to a United States attorney, who decides whether prosecution is warranted..$^{366}$

Due in large measure to the courts' interpretation of the liberal criminal fraud statute, conviction followed prosecution in ninety-nine percent of the cases tried in fiscal 1964.367 Less needs to be proved to obtain a conviction under the mail fraud statute than is required for criminal fraud

35718 U.S.C. $\$ 1341$ (1964).

35874 Stat. 654 (1960), 39 U..S.C. $\$ 4005$ (1964).

359110 CoNG. REC. 1958 (1964); 108 Cong. ReC. $4168-71$ (1962).

360 Interview With Assistant United States Attorney.

361 See note 29 supra and accompanying text.

362 Interview With Postal Inspector, Philadelphia Post Office.

363 U.S. Post OfFice DeP'T, How the Postal Inspection Service Protects You Against MaIr Fraud (1964).

364 Most such complaints are made directly by consumers. Interview With Postal Inspector, Philadelphia Post Office. Of the small number of complaints that do not come directly from consumers, by far the majority originate with consumer complaints to postmasters, local law enforcement agencies, and federal agencies such as the FTC and the FBI.

365 The Philadelphia Post Office settles over a thousand complaints a year, both civil matters and potential violations of the mail fraud statute, by this informal method. The procedure adopted by the Post Office is similar to that adopted by the Philadelphia District Attorney's office. See notes 304-07 supra and accompanying text.

366 Post Office Dep't, The Postal Inspection Service (1963).

367 Figures Released by the Post Office Department. These figures are the same for fiscal 1962. Post Office Dep't, The Postal Inspection Service (1963). During fiscal 1964, 709 mail fraud arrests were obtained, 4,779 questionable promotions were discontinued, and 119,092 complaints were received. Hearing Before the House Subcommittee on Appropriations, 89th Cong., 1st Sess. (1965) [hereinafter cited as Post Office Appropriation]. But cf. New Republic, Aug. 21, 1965, p. 7 (suggesting that the $99 \%$ conviction rate in all Post Office cases results from fact that "the vast majority of cases ... are never brought to trial, either because of insufficient evidence or because an investigation has shaken up a suspect enough to make him stop his supposed violation"). 
prosecution under the law of most states. ${ }^{368}$ The federal statute only requires proof of "(1) a scheme to defraud and (2) the mailing of a letter, etc., for the purpose of executing the scheme." ${ }^{369}$ There is no requirement that anyone be defrauded or even that a likelihood exist that someone will be defrauded.370 Misrepresentation of an existing fact need not be shown. It is only necessary to prove use of the mails to further a scheme designed to deceive persons of ordinary prudence. ${ }^{371}$ Thus, a scheme to defraud can be found if consumers of reasonable prudence are led to believe that they will obtain something worth more than its actual value, even if "the articles to be sold will approximate in commercial value the price to be asked and received." 372 In short, courts "will find fraud in the type of exaggeration of the worth of goods-'trader's talk' or 'puffing,' as it is called,-which is tolerated in the law of civil liability." 373

While proof of intent to defraud is a reasonable requisite for conviction under the criminal statute, ${ }^{374}$ the effectiveness of the Post Office is impaired by the Supreme Court's interpretation requiring a similar showing under the administrative statute. ${ }^{375}$ In Reilly $v$. Pinkus ${ }^{376}$ the Court reasoned that while the Federal Trade Commission has the authority to issue cease and desist orders without proof of fraudulent intent, ${ }^{377}$ the FTC order "does not approach the severity of a mail fraud order" 378 which prevents the fraudulent seller from receiving mail. The Court stated that though an FTC order would force a business to change certain policies the business would be able to sell its product as before while a Postmaster's order, preventing an offender from receiving incoming mail, "could wholly destroy a business." 379

The Court did not consider, however, that just as an individual who conforms to an FTC cease and desist order can continue to operate his business, so can a postal offender receive his mail and maintain his business if he stops the misleading practice. Furthermore, the requirement of finding intent to defraud is not necessary to fulfill the statutory purpose

368 See discussion of state false pretenses statutes, notes 227-233 supra and accompanying text.

369 Pereira v. United States, 347 U.S. 1, 8 (1954).

370 E.g., Hermansen v. United States, 230 F.2d 173-74 (5th Cir.), cert. denied, 351 U.S. 924 (1956) ; United States v. Sylvanus, 192 F.2d 96, 106 (7th Cir. 1951), cert. denied, 342 U.S. 943 (1952).

371 E.g.y Silverman v. United States, 213 F.2d 405 (5th Cir.), cert. denied, 348 U.S. 828 (1954); Fournier v. United States, 58 F.2d 3 (7th Cir.), cert. denied, 286 U.S. 565 (1932).

372 Rude v. United States, 74 F.2d 673, 676 (10th Cir. 1935).

373 United States v. Whitmore, 97 F. Supp. 733, 736 (S.D. Cal. 1951).

374 The Post Office agrees that it is "fair and equitable" to have to prove intent in a criminal prosecution. REPORT ON FRAUDS 78 (testimony of Henry B. Montague, Chief Postal Inspector).

37574 Stat. 654 (1960), 39 U.S.C. § 4005 (1964).

376338 U.S. 269 (1949).

377 See 38 Stat. 718 (1914), as amended, 15 U.S.C. $\S 45$ (b) (1964).

378 Reilly v. Pinkus, 338 U.S. 269, 277 (1949).

379 Ibid. 
which is to afford "the necessary protection in preventing the operator from receiving the remittance from the public," 380 rather than to punish the violator. Moreover, the difficulty in obtaining the necessary evidence to establish intent makes rapid action against offenders much less likely and thus hampers public protection. ${ }^{381}$ This problem is further complicated by the Post Office's lack of subpoena power, which forces it to rely in many instances on a prima facie showing of intent. ${ }^{.82}$

A solution to this Post Office dilemma has been offered in a recent Senate amendment. ${ }^{383}$ It eliminates the requirement of proving intent precedent to administrative action by deleting the word "fraudulent" from the statute and substituting the word "misleading." Furthermore, the amendment explicitly states that the required pretenses, representations and promises need not be intentiona1.384 Adoption of the amendment would greatly strengthen the Post Office's ability to curb fraudulent mail practices.

Notwithstanding the difficulties imposed by the present interpretation of the administrative statute, the postal inspectors have a reputation for rapid processing of complaints. Although hampered by a small staff ${ }^{385}$ and an increasing number of charges of mail fraud, ${ }^{388}$ their authority to reach activities beyond those which the states are empowered to control combined with some success in obtaining restitution for defrauded buyers, ${ }^{387}$ leads many consumers to turn more readily to the Post Office than to local law enforcement agencies. ${ }^{388}$

\section{B. Federal Trade Commission}

The Federal Trade Commission's jurisdiction over "deceptive acts or practices" ${ }^{389}$ in advertising represents another major governmental effort in the fraud prevention field. The Commission initially had to formulate "some minimal standard of public competence below which the law will

380111 Cong. Rec. 3997 (daily ed. March 4, 1965) (statement of Chief Postal Inspector Montague).

381 See Report on Frauds 78.

382111 Cong. Rec. 3997 (daily ed. March 4, 1965) (statement of Chief Postal Inspector Montague).

383 S. 1364, 89th Cong., 1st Sess. (1965).

384 S. 1364, 89th Cong., 1st Sess. $\$ 1$ (1965).

385 See description of mail fraud activities and limitations and request for 15 additional inspectors. Post Office Appropriations 190-91, 196.

386 Chief Postai Inspector, Post Office Dep't, 30 Inspection Service BulleTIN 14 (April-May 1965).

387 Refunds, either voluntary or court ordered, amounted to over nine million dollars in fiscal 1964. Post Office Appropriations 190. The Postal Inspection Service states, however, that "the American public is bilked of over a $\$ 100$ million a year through mail fraud." POST OFFICE DEP'T, How tHe POSTAL INSPECTION SERvice Protects You Against MaIL Fraud (1964).

388 Interview With Better Business Bureau Official.

38952 Stat. 111 (1938), as amended, 15 U.S.C. $\$ 45(a)(1)$ (1964). "The framers and enactors [of the Federal Trade Commission Act] were not even concerned with the problem of false advertising." Millstein, The Federal Trade Commission and False Advertising, 64 CoLUM. L. REv. 439, 450 (1964) [hereinafter cited as Millstein]. Yet it has been said that the FTC's greatest accomplishments have 
afford no protection against deception." 390 Rather than adopt the reasonable man standard, "the FTC has selected an extremely low intelligence level," 391 with the result that practices, which would not deceive a reasonable man are prohibited and "the courts have not significantly disturbed its determination. . . ." 392 Thus, in Charles of the Ritz Distrib. Corp. v. FTC, ${ }^{393}$ the petitioner contended that the advertisement of its cosmetic preparation "Rejuvenescence" was not deceptive, on the ground that "no straight-thinking person could believe that its cream would actually rejuvenate." 394 The court rejected this contention reasoning that "while the wise and the worldly" would realize that the misrepresentations were false, "there remains 'that vast multitude' of others who, like Ponce de Leon, still seek a perpetual fountain of youth." 395

In other areas the courts have also permitted the FTC wide latitude to develop broad concepts in the determination of what constitutes deceptive advertising. Thus the standard of "literal truthfulness" 396 has been extended to prohibit advertisements literally correct but phrased to create misleading impressions, ${ }^{397}$ and those in which material facts are not revealed. ${ }^{398}$ Furthermore, while mere expressions of personal evaluations of a product's intangible qualities may not constitute an actionable promise, if the superlative can be disproved objectively, the Commission may order the advertising stopped by considering it outside the area of "trade puffing." 380

Despite the FTC's broad reach, its efforts, as well as those of legislative and other self-regulatory bodies, have been branded as "notoriously

been in the elimination of deceptive practices. Weston, Deceptive Practices and the Federal Trade Commission: Decline of Caveat Emptor, 24 FEn. B.J. 548, 549 (1964) [hereinafter cited as Weston]. During fiscal 1964, more than a half million radio and television scripts and a quarter of a million pages of printed material were screened by the FTC. "From this total, 42,646 advertisements were forwarded for consideration by the legal staff." 1964 FTC ANN. REP. 16.

300 Note, The Regulation of Advertising, 56 CoLUM. L. REv. 1018, 1030 (1956). 391 Millstein 458; see $i d$. at 458-62. Indeed Millstein states that this intelligence level is "remarkably low-so low in fact that one may rightly wonder why no significant challenge has been made in the courts to this possibly unconstitutional abridgement of speech." Id. at 462 .

$382 I d$. at 458 .

393143 F.2d 676 (2d Cir. 1944).

$394 I d$. at 679 .

$305 I d$. at 680 .

306 Id. at 680, citing Moretrench Corp. v. FTC, 127 F.2d 792, 795 (2d Cir. 1942).

397 See Millstein 466-68 \& n.119; Weston 556; Note, 56 Cozum. L. Rev. 1018, 1027 (1956). Another aspect of this rule condemns the truthful statement which does not support the product claim. Millstein 468.

398 The Wheeler-Lea Amendment of 1938 introduced the statutory concept that failure to reveal certain important information may be considered unfair and deceptive in the advertising of food, drugs, devices and cosmetics. 52 Stat. 114 (1938), as amended, 15 U.S.C. \$55(a) (1) (1964). The courts have permitted the FTC to apply this principle in reviewing advertisements of other kinds of products. Weston 556-57.

399 Millstein 469 . While the line between objective and subjective claims is difficult to draw, courts have generally upheld the Commission's decision. Id. at $469-70$. 
ineffective." 400 The basic cause of this ineffectiveness is the limited scope of the Commission's enforcement powers. The Commission "had no power of its own to imprison, fine, or assess or award damages. Its maximum authority is to issue an order to 'cease and desist,' and even this order can be appealed to the courts within 60 days after it is issued." 401 These problems have led a Senate subcommittee, after full investigation of the work of the FTC, to question whether even "proposed improvements would be more than patches on an old structure in need of thorough examination." 402

Furthermore, the effectiveness of the FTC's power to issue cease and desist orders has been severely hampered "by the Commission's inability to make expeditious determinations." 403 Cases take about a year to reach the Commission level for issuance of a complaint.40: At this time, the respondent can consent to a cease and desist order without admitting any violation of the law. ${ }^{405}$ If consent is not obtained, however, there is frequently a delay of three to five years between issuance of the complaint and the time when a cease and desist order becomes final through exhaustion of the last opportunity for appeal. 406 During this period the objectionable practice will continue, as the FTC Chairman stated, even "if on its face it is . . . phony, and we can show upon the record the irreparable harm and injury that will come to the public." ${ }^{407}$ This administrative lag is so long that it has been suggested on more than one occasion that some affluent advertisers deliberately take advantage of complex Commission procedures and court struggles in order to continue sales of misrepresented, but lucrative products for as long as they possibly can. ${ }^{408}$

Many of those interviewed pointed to the continued operation of the Holland Furnace Company as a "classic example" of administrative inefficiency. Complaints about the high-pressure tactics of Holland salesmen can be traced as far back as the early 1930's. ${ }^{409}$ In December, 1936, after an FTC investigation, a stipulation was filed whereby the company agreed to cease and desist from using certain misleading advertising claims. ${ }^{410}$ Although the FTC and various better business bureaus continued to receive

400 Warne, Advertising-A Critic's View, J. Marketing, Oct. 1962, p. 13. See also criticisms of the FTC in Weston 548 n.4. But see OGILvY, CoNFESSIONS OF AN AdVERTISING MAN 93 (1963) (advertising executive's fear of the FTC), and Weston 549 (statements of defenders of FTC effectiveness).

401 FTC, Here is Your Federad Trade Commission 4 (1964).

402 Report on Frauns 85.

403 Note, 56 Colum. L. Rev. 1018, 1035 (1956). See generally Weston 563-65. 404 Report on Frauns 81 (testimony of FTC Chairman Paul Rand Dixon). 105 Ibid.

406 Weston 561 . The use of delaying tactics by skilled lawyers "can sometimes postpone the day of reckoning even longer." Ibid.

407 Report ON FRAUDS 82-87; accord, Weston 561.

408 REPORT ON FraUdS 82.

409 Consumer Bull., April 1965, p. 25.

41024 F.T.C. 1413-14 (1936). Holland "agreed to cease and desist from the use in its advertising matter, or otherwise, of the statement, "Find out why only Holland can guarantee perfect heat in every room ..." 
numerous complaints about Holland's activities, ${ }^{411}$ it was not until May of 1954 that a second complaint was entered by the FTC.112 Four years later a cease and desist order was issued prohibiting Holland "from engaging in a sales scheme . . . whereby salesmen gain access to homes by misrepresenting themselves as official 'inspectors' and 'heating engineers' and thereafter dismantling furnaces on the pretext that this is necessary to determine the extent of necessary repairs." 413

The company refused even at this juncture to discontinue its deceptive practices and seven years passed before company officials were heavily fined for disobeying a court order enforcing a 1958 cease and desist order. ${ }^{\mathbf{1 1 4}}$

In the fields of drugs, food, devices or cosmetics, the Commission has the power, although unfortunately it is seldom used, ${ }^{415}$ to petition the court to enjoin the dissemination of any advertisement that is not in the public interest. ${ }^{416}$ This temporary injunction remains in effect until the complaint is dismissed by the Commission, or the order to cease and desist becomes final or is set aside by the court on review. In other areas, however, the FTC cannot apply for an injunction until after a cease and desist order has been issued and respondent has exercised an option to appeal.117 Both Presidents Kennedy and Johnson have supported proposals which would permit the FTC to issue preliminary injunctions in all advertising fields without court application. ${ }^{418}$ Bills to this effect ${ }^{419}$ have been strongly opposed and have little prospect of enactment.420 Experts in FTC procedure have proposed, as a "logical solution," 421 expansion of the FTC's temporary injunction powers in the drug, food, device and cosmetic area ${ }^{422}$ to include all types of products and an explicit liberalization of the tests courts apply in granting such injunctions. ${ }^{423}$

411 Consumer Bull., April 1965, pp. 25-26.

412 Holland Furnace Co., 55 F.T.C. 55 (1958).

413 Id. at 91 . The Commission's order was upheld by the circuit court in Holland Furnace Co. v. FTC, 269 F.2d 203 (7th Cir. 1959), cert. denied, 361 U.S. 932 (1960), and again in Holland Furnace Co. v. FTC, 295 F.2d 302 (7th Cir. 1961).

414 In re Holland Furnace Co., 341 F.2d 548 (7th Cir.), cert. denied, 381 U.S.

924 (1965).

415 Weston $551-52$ \& n.26.

41652 Stat. 114 (1938), 15 U.S.C. $\$ 53$ (1964).

417 Note, 56 CoLum. L. REv. 1018, $1035 \mathrm{n} .95$ (1956) ; see 38 Stat. 719 (1914), as amended, 15 U.S.C. $\$ 45$ (c) (1964). Weston notes that in one case the FTC obtained a preliminary injunction to stop a lottery pending the appeal, but "for some reason the FTC does not appear to have pressed this precedent to any extent. . . " Weston 561 n.111.

418110 Cong. Rec. 1959 (1964) ; 108 Cong. Rec. 4170 (1962).

419 E.g., H.R. 8830, 87th Cong. 1st Sess. (1961) ; Weston 562 n.113.

420 RePORT ON FraUdS 83; Millstein 493 n.263; Weston 562.

421 Millstein 493.

422 See note 413 sipra and accompanying text.

423 Millstein 493; Weston 562-63. Weston suggests that they should have to find only that the type of violation alleged has previously been labelled unfair by the courts; that respondent is using such a practice; and that there is a likelihood that consumers or competitors might be hurt by its continuation. Weston 563 . Millstein believes that such applications should "be judged by the common law standards applicable to the granting of such drastic relief." Millstein 493. 


\section{Suggested Federal Programs}

The increased attention given the federal government's consumer protection activities, has generated a new approach to consumer problems. Many of the seeds for a change in philosophy were planted by a citizen's advisory committee's study of the programs and policies of the federal Food and Drug Administration. ${ }^{424}$ The recommendations resulting from this study differed from the usual requests for additional legislation or changes in investigation and prosecution activities. Instead, the citizen's committee suggested that the FDA concentrate its activities on a program of public education in consumer protection and development of an industry self-regulation program. ${ }^{425}$ To improve federal-state cooperation, the report urged the development of FDA programs to strengthen the state laws and administrative agencies, a thorough study of state capabilities, improved federal-state training programs, and the development of a genuine interest throughout the FDA in obtaining the greatest possible consumer protection by coordinated harnessing of all regulatory programs-federal, state and local. ${ }^{428}$

As suggested by the Chairman of the American Bar Association Subcommittee on Regulations Affecting Advertising, the Report's overall view that "the philosophy of administration should be reoriented," 427 seems "equally applicable, in part at least, to the FTC." ${ }^{428} \mathrm{He}$ called for an overhaul of the FTC's function whereby:

The commission should occupy a primus inter pares role with respect to state agencies: encouraging passage of needed legislation; offering advice and possibly assistance in litigation and the formulation of guides; becoming the focal point of coordination among state agencies to avoid inconsistencies ; referring complaints of an essentially local nature to state agencies; and, in general, developing programs designed to urge and aid state agencies to adopt a rational but consistent approach to local advertising, thereby relieving the Commission of a host of essentially local matters. ${ }^{429}$

The suggestion that the FTC "doff its almost exclusively prosecutorial hat and don that of advisor and coordinator to the states' attorneys general and to self-regulatory bodies," 430 was more clearly defined and explained

424 Report of Second Citizens Advisory Committee on the Food \& Drug AdMINISTRation (1962) (report to Secretary of Health, Education and Welfare).

425 Id. at 14-15.

$428 \mathrm{Id}$. at 10 .

$427 \mathrm{Id}$. at 14 .

428 Millstein 498.

$429 \mathrm{Id}$. at 497.

$430 \mathrm{Id}$. at 495 . 
in the Federal Bar Journal's symposium. Besides outlining specific programs for state coordination and legislation, a section of the symposium suggested methods by which the FTC could stimulate self-regulation. ${ }^{431}$ It also proposed that the Commission enhance the effectiveness of consumer organizations, by encouraging these groups to publish forms to facilitate consumer filing of complaints and by giving greater aid to consumer organizations in product testing. ${ }^{432}$ This philosophy of the role of the FDA and the FTC is representative of the need for emphasizing the federal government's role as advisor and coordinator in each of the other twenty agencies engaged in consumer activities. ${ }^{433}$ Fraud can be greatly reduced if governmental organizations join with state and local law enforcement officials and private groups in a coordinated program.

\section{Education}

Everyone interviewed for this study emphasized the importance of consumer education as a method of combating unethical business practices. While recognition of the need for consumer education has spurred the development of programs by numerous organizations, many persons share the concern of a better business bureau official who questions whether the programs "reach people for whom they are intended." 434 A massive drive by every group concerned to reach all consumers, especially "the poor who suffer most from sharp practices," ${ }^{435}$ has been suggested as the only long term solution.

President Johnson's message to Congress on consumer interests ${ }^{436}$ presented an excellent outline from which the needed advances in consumer education can be developed. He directed his Committee on Consumer Interests to:

\section{"Examine the many programs for consumer education in our schools." 437}

If schools are to prepare a youth adequately for society, they must teach him how to make intelligent decisions in the market place. A plan with this goal has been introduced in a New York high school which provides programs concerning the decisions involved in purchasing automobiles, the intricacies in reading labels with their "semi-hidden information," and the techniques of a "bait and switch" sale.438 Consumer education also is integrated into the mathematics course by teaching

431 Weston at $575-77$.

432 Id. at 577 .

433 See note 346 supra and accompanying text.

434 REPORT ON FRAUDS 21 (testimony on efforts to warn elderly and others against danger of quackery and other consumer frauds and misrepresentations).

435110 CoNG. REC. 1958, 1960 (1964).

438 Id. at 1958.

437 Id. at 1960. (Emphasis added.)

438 N.Y. Times, Aug. 15, 1965, §4, p. 7. 
students how to determine the real cost of a loan and an installment purchase. English classes include an analysis of the advertising agency's "propaganda techniques." 439 Another approach has been adopted by the Philadelphia school system which distributes a series of skits for children in the lower grades to perform, depicting some of the more typical fraudulent schemes that the student may encounter as an adult. ${ }^{440}$

" $[D]$ evelop as promptly as possible effective ways and means of reaching more homes and more families-particularly low-income familieswith information to help them get the most for their money." 441

Great quantities of information are available to interested individuals. Two magazines, Consumer Reports and Consumer Bulletin, are published monthly by organizations which are often commended for their "excellent product-testing and educational endeavors." ${ }^{442}$ A congressional survey of government protection activities also reported that eight agencies conduct direct consumer education programs. ${ }^{443}$ In addition, many state consumer councils publish booklets which are made available to interested individuals and groups, ${ }^{444}$ and the better business bureaus offer for sale, at a nominal sum, a series of booklets that warn against fraudulent schemes. ${ }^{445}$

Yet, as President Johnson has indicated, these publications "often do not penetrate to the lowest 20 percent of the nation's income groups." 446 The median income of a Consumer Report subscriber, for example, is over 10,000 dollars a year, and he has a college degree. ${ }^{447}$ While consumer

439 Ibid. The New York Times reports that this model for consumer education in schools "has not been greeted with unqualified enthusiasm." An article in a newsletter published by Grey Advertising, Inc. "expressed concern that consumer education might be brainwashing." Ibid.

440 Thirteen of these skits are on file in Biddle Law Library, University of Pennsylvania. They include "The Settlement House Racket," "The C.O.D. Racket," "The Vanishing Suit" and "Just Sign on the Dotted Line."

441110 Cong. Rec. 1960 (1964). (Emphasis added.)

442 Weston 558. Besides publishing monthly magazines and an annual compilation of product tests, these consumer organizations perform other valuable functions. Consumers Union testifies before congressional committees in support of consumer protection legislation, supports outside research organizations such as the Survey Research at the University of Michigan, and supports various movements that will aid the public such as the campaign stressing the importance of seat belts and better medical care. Sales Management, April 2, 1965, p. 26. Consismers Research sends slides and booklets to schools as part of its consumer education program, lectures to various church and civic groups, and writes books on consumer topics. Interview With F. J. Schlink, President and Technical Director, Consumers Research.

443 House Comm. on Government Operation, Consumer Protection Activities of Federal Departments and Agencies. H.R. ReP. No. 1241, 87th Cong., 1st Sess. 28 (1961). One example is the Federal Trade Commission's publication of guides against deceptive advertising practices. Ibid.

444 E.g., note 291 supra (New York) ; California Consumer Counsel Rep. 31 (1962) (publication of "Credit Costs Money-Know How Much It Costs You," "New Consumer Laws Protect You," "How To Use the Small Claims Court."), Wisconsin Department of Agriculture's Consumer's Guide to Careful Buying; Attorney General of Michigan's Consumer Handbook.

445 Better Business Bureau, Fact Booklets (list of 24 booklets available to the public).

446110 Cong. Rec. 1960 (1964).

447 Interview With Dr. Colston E. Warne, President of Consumers Union. 
magazines are subject to the criticism that "they have neglected to make sufficient use of the techniques of modern advertising to build their membership [s]," 448 much of the problem appears to stem from the fact that poor people, even if cognizant of the existence of consumer magazines, would not read or buy them. ${ }^{449}$ Publications of federal agencies and those of state and local organizations also do not reach the public in large numbers. Most booklets are available only on request, and the individual who writes for such information generally is not the person who most needs protection from fraud. ${ }^{450}$ While many consumer organizations attempt wide dissemination of information, ${ }^{451}$ most members of the public usually hear or read only spot announcements by the better business bureau or accounts of particularly egregious frauds in local newspapers. ${ }^{452}$

Many doubt whether the present availability of such information can change purchasing habits and call for new and expanded techniques which will reach low income groups. The better business bureau's program of making announcements in the mass media about fraudulent operations ${ }^{453}$ should be expanded and local chambers of commerce in municipalities without a bureau should assume this function. Newspapers also should be encouraged to publish weekly columns to educate the public.454 Existing programs by consumer oriented organizations for delivering lectures and showing slides and movies ${ }^{455}$ should be increased. Greater attempts must also be made by these groups and the mass media to inform the consumer of the procedures for registering effective complaints when he believes he has been defrauded. ${ }^{456}$ In addition, attempts must be made to have those individuals who work closely with the poor and elderly provide them with

448 Weston 558. Consumer Reports is the country's largest consumer magazine with a circulation of more than 950,000. Interview With Dr. Colston $\mathrm{E}$. Warne, President of Consumers Union. Consunter Bulletin's circulation is 100,000 . Interview With F. J. Schlink, President and Technical Director, Consumers Research.

449 Dr. Colston E. Warne, President of Consumers Union reports that during the 1930 's his organization published a special $\$ 1.00$ edition geared to the poor consumer as well as a $\$ 3.00$ regular edition. Warne indicated that the more expensive edition "did very well" while the special edition "did not sell."

450 Interview With Iegal Aid Counsel.

451 Better Business Bureau publications, for example, are distributed to all member organizations and their employees. Interview With Better Business Bureau Official.

452 Consensus of Interviews.

453 During 1964, the Bureat reported 79,418 radio spots and 23,212 television announcements. BetTER Business BUREAU, Statistics for 1964 (1965).

454 Ohio Memorandum 4-5.

465 Members of the New York Bureau show their film "Caveat Emptor" to all groups upon request. N.Y. Report 7. Three Better Business Bureau films are also available without charge, "The Better Business Bureau Story," "To Serve the Living," and "Too Good To Be True." 43 The Shield, No. 1, Jan. 1, 1963.

456 In Caplovitz's study of low income consumers, he found that $64 \%$ could not name a single agency dealing with protecting him from fraud. Only $3 \%$ of the families said they would turn to a private lawyer if they were cheated by a merchant. Caplovitz, Colwsumer Problems, 23 Legar AID BRIEF CASE 143, 147 (1965). Consumer organizations are trying to remedy this situation by publicizing their activities as well as those of other similar groups. See, e.g., "How To Complain," The Herald Tribune, March 7, 1965, p. 4 (magazine); The Consumer in the 
reliable information. As stated by one commentator, "should we not instruct the various workers-doctors, nurses, social service personnel, guidance specialists, and other caretakers-how to help people help themselves in their communities?" 457

\section{"[B]egin a series of regional consumer conferences." 458}

The coordination of activities by representatives of consumer councils, better business bureaus, manufacturers, advertising agencies, mass media, retailers, and government agencies, could also be a useful way of eliminating consumer ignorance. A step beyond the President's regional planning meetings can be taken if each state and municipality similarily coordinates plans to assure that every purchaser has adequate knowledge to make intelligent decisions in the market place.

\section{As President Johnson stated to Congress:}

$[F]$ or far too long, the consumer has had too little voice and too little weight in government.

As a worker, as a businessman, as a farmer, as a lawyer or doctor, the citizen has been well represented. But as a consumer, he has had to take a back seat. That situation is changing. The consumer is moving forward. We cannot rest content until he is in the front row, not displacing the interests of the producer, yet gaining equal rank and representation with that interest. . . .

What is new is the concern for the total interest of the con sumer, the recognition of certain basic consumer rights: The right to safety, the right to be informed, the right to choose, the right to be heard. ${ }^{459}$

Marketplace 6-8 (Consumers' Research, Inc. 1964), on file in Biddle Law Library, University of Pennsylvania; FTC, Fight Back! The Ungentle Art of Self Defense, on file in Biddle Law Library, University of Pennsylvania; Attorney General of Michigan's Consumers' Handbook.

457 RePORT ON FraUdS 21 (testimony of Irving Ladimer, Vice President and Director of the Food, Drug, and Cosmetic Division, National Better Business Bureau, Inc.).

458110 Cong. Rec. 1958, 1960 (1964). (Emphasis added.)

459 Id. at 1958. (Emphasis added.) 